\title{
WestVirginiaUniversity
}

THE RESEARCH REPOSITORY @ WVU

Graduate Theses, Dissertations, and Problem Reports

2018

\section{Con el Nopal en la Frente}

\author{
Tessa Lee Martinez
}

Follow this and additional works at: https://researchrepository.wvu.edu/etd

\section{Recommended Citation}

Martinez, Tessa Lee, "Con el Nopal en la Frente" (2018). Graduate Theses, Dissertations, and Problem Reports. 6170.

https://researchrepository.wvu.edu/etd/6170

This Thesis is protected by copyright and/or related rights. It has been brought to you by the The Research Repository @ WVU with permission from the rights-holder(s). You are free to use this Thesis in any way that is permitted by the copyright and related rights legislation that applies to your use. For other uses you must obtain permission from the rights-holder(s) directly, unless additional rights are indicated by a Creative Commons license in the record and/ or on the work itself. This Thesis has been accepted for inclusion in WVU Graduate Theses, Dissertations, and Problem Reports collection by an authorized administrator of The Research Repository @ WVU. For more information, please contact researchrepository@mail.wvu.edu. 


\title{
CON EL NOPAL EN LA FRENTE
}

\author{
Tessa Lee Martinez
}

Thesis submitted

to the College of Creative Arts

at West Virginia University

in partial fulfillment of the requirements for the degree of

Master of Fine Arts in

Ceramics

\author{
Shoji Satake, M.F.A., chair \\ Robert Moore, M.F.A. \\ Eve Faulkes, M.F.A. \\ Alison Helm, M.F.A. \\ Department of Art and Design \\ Morgantown, West Virginia \\ 2018
}

Keywords: Xenophobia, Racism, Microaggressions, Foreignness

Copyright 2018 Tessa Lee Martinez 


\section{ABSTRACT \\ Con el Nopal en la Frente}

\section{Tessa Lee Martinez}

This MFA thesis addresses work completed and presented in a thesis exhibition at West Virginia University as well as significant influences and events that relate to process and concept. Con el Nopal en la Frente (With a Cactus on your Forehead) is an installation that consists of several ceramic sculptures that reference elements of a landscape typical in southwest Texas. Using symbols and phrases that are common along the Texas-Mexico border, this thesis and supporting exhibition investigates contemporary expressions of xenophobia. During my years away from home, the presence of microaggressions and racist remarks, said both intentionally and unintentionally, was common. This was new to me. Often, those saying these comments did not understand why their remarks were considered insulting or bigoted. The goal of this work is to offer the opportunity for viewers to contemplate how their remarks, no matter the intent, are pointed implications of foreignness. 


\section{DEDICATION}

I would like to dedicate this thesis to my Buelito who always said, "hechale ganas en la escuela."

I would also like to dedicate this to my loving parents and little sisters; We did it! And to my buelitas, tios, tias, primos y primas, this is for you too. 


\section{ACKNOWLEDGEMENTS}

I would like to take this moment to thank the West Virginia University faculty for accepting me as their graduate student and allowing me the opportunity to teach their students. I would like to thank the members of my committee, Shoji Satake, Robert Moore, Alison Helm, and Eve Faulkes, who contributed to the development of my work.

I want to thank my parents, Jose and Diana Martinez, who were taking their first big steps at the same time I was. I would like to thank my sisters Ruby, Krista, and Renatta. Whenever I began to doubt myself I had three reasons not to. I would like to express my sincerest gratitude to Joseph Lupo and Jason Lee for always meeting with me to discuss both the useless and important. I would like to thank my ceramic parents, Angela Carbone and David Bogus; even with contradicting personalities, ideas, advice, work styles, and feedback, my well-being was always in their best interest. I would like to thank Jeanette Hatcher for all her words of encouragement and for motivating me to go to graduate school. I would like to thank all my helpers. There were far too many to properly list here but can be found in Appendix A. Lastly, I want to thank my partner Jacob Guzan for his support, criticism, assistance, and technical insight during my graduate school experience. 


\section{TABLE OF CONTENTS}

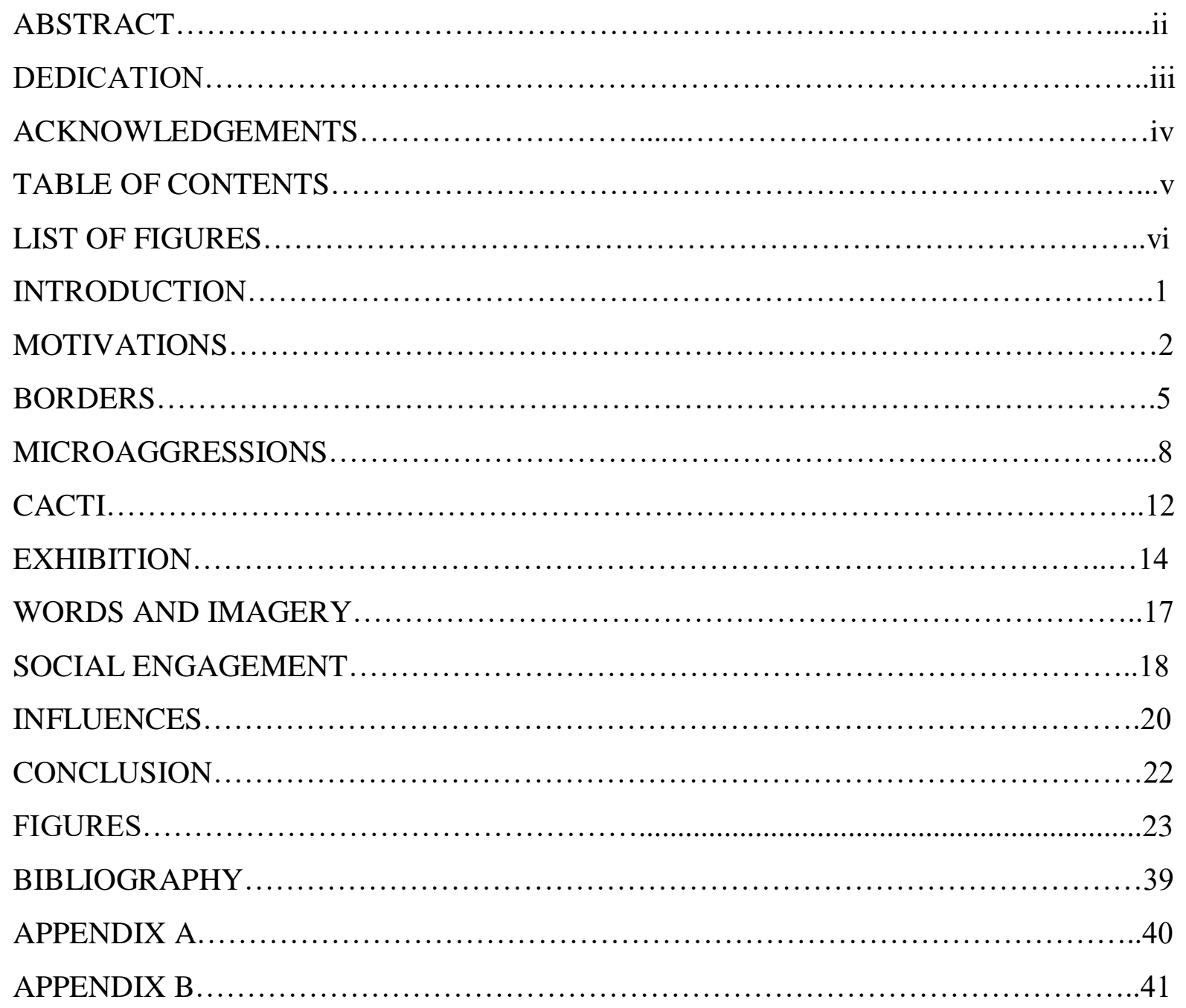




\section{LIST OF FIGURES}

Figure 1. Tessa Lee Martinez, Con el Nopal en la Frente (Vestibule), 2018...................23

Figure 2. Tessa Lee Martinez, ;Aguas!, 2018............................................23

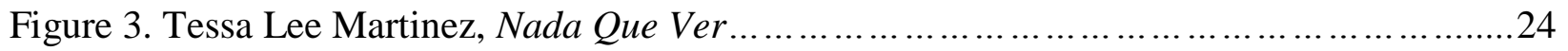

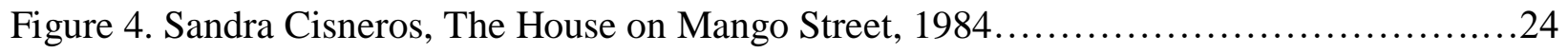

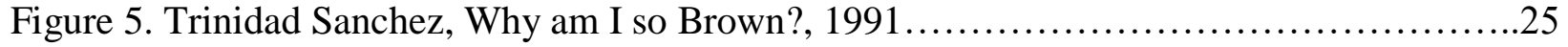

Figure 6. Pat Mora, The Desert is My Mother, 1994.....................................25

Figure 7. Cuate Santos, Mayors Exchanging Flags at International Bridge Ceremony, 2018....26

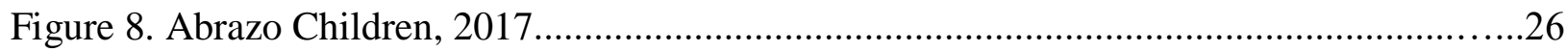

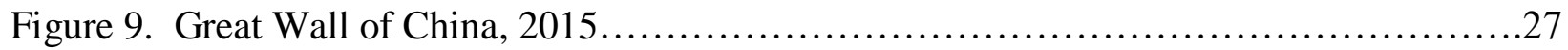

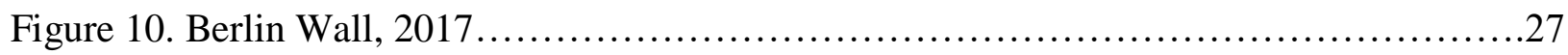

Figure 11. Iron Curtain Trail, 2017..............................................28

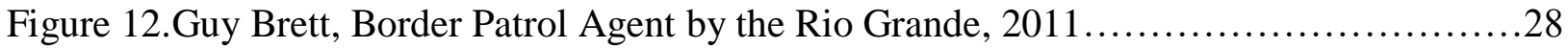

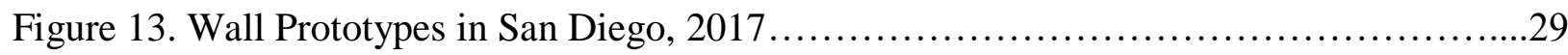

Figure 14. Mona Hatoum, Grater Divide, 2002......................................29

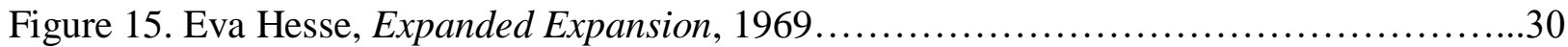

Figure 16. Tessa Lee Martinez, How much harder do I have to scrub so that I can become white?

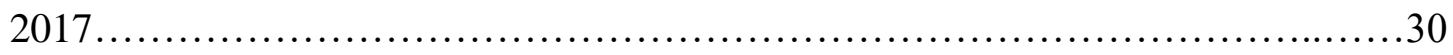

Figure 17. Tessa Lee Martinez, Recoger y Escoger, 2017..................................31

Figure 18. Charles Beneke, Disruption: This is Real, 2017............................. 31

Figure 19. Tessa Lee Martinez, detail of Surface Tension, 2017.............................32

Figure 20. Tessa Lee Martinez, detail of Nada Que Ver, 2018................................32

Figure 21. Helen Richter Watson with her work, n.d................................. 33

Figure 22. Christina Erives, Sin Titulo, 2016...................................... 33

Figure 23. Tessa Lee Martinez, detail of jAguas!, 2018..................................34

Figure 24. Antony Gormley, Field Project, 1989...................................... 34

Figure 25. Ila Sahai Prouty, Paper Bag Test, 2016.................................... 35

Figure 26. Tessa Lee Martinez, Nada Que Ver (audience response), 2018.....................35

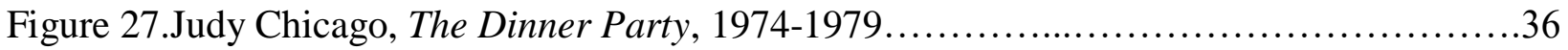


Figure 28. Christine Sun Kim, Game of Skill 2.0, 2015............................... 36

Figure 29. Adrian Piper, My Calling (Card) \#1, 1986................................... 37

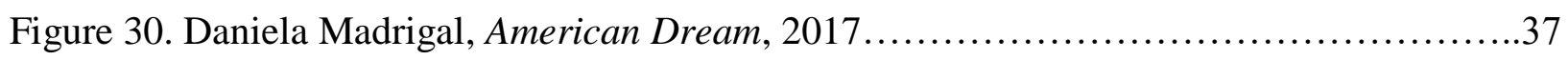

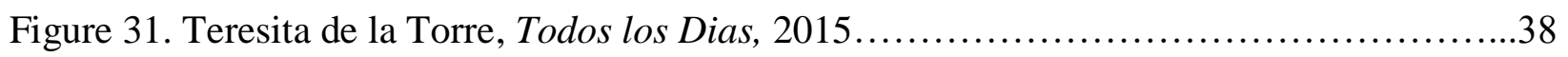

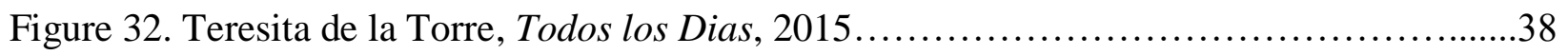




\section{INTRODUCTION}

Con el Nopal en la Frente stems from my recent experiences away from my home in Texas (2018, fig. 1). This installation contains two main works. Several sculptures of ceramic cacti were created in reference to the cacti that grow in southwest Texas (2018, fig. 2$)$. These were arranged in clusters and surrounded by sand. Behind the cacti is a towering wall to represent the proposed structure at the border of the United States and Mexico (2018, fig. 3).

This exhibition investigates the normalization of contemporary expressions of xenophobia. I employ symbols and phrases that are common along the Texas-Mexico border. This location is both my home and a place that is greatly affected by current national politics. During my years away from home, the presence of microaggressions and racist remarks, said both intentionally and unintentionally, became common. These suggestions of otherness made me feel like a foreigner in my own country. Con el Nopal en la Frente merges the place I consider my home with the feeling of being "out of place". 


\section{MOTIVATIONS}

As a child growing up on the border of southwest Texas and Mexico, a traditional Hispanic upbringing was common. Laredo, Texas is a city along the Rio Grande with a population that is over $95 \%$ Hispanic. Many people of the city are either immigrants or descendants of immigrants from Mexico. Due to Laredo’s proximity to Mexico, a bilingual early childhood education was enforced. At an early age, our curriculum included Mexican history, culture, social issues, and Spanish literature and language in addition to the standard curriculum about the United States. Books from my childhood such as The House on Mango Street (fig. 4), Why am I so Brown? (fig. 5), and The Desert is my Mother (fig .6) had an impact on me. The collection of short stories and poems in these books examined growing up in the United States from the point of view of someone who was Hispanic, which I found to be relatable and inspiring. Often times these books were a combination of English and Spanish. Learning the history of Mexico and being able to speak Spanish was not seen as an advantage but rather a necessity in Laredo. As the nation's largest inland port of entry, Laredo's economy and character is largely due to business, trade, and networking with Mexico.

Laredo, an American city so geographically, economically, and culturally intertwined with Mexico has an annual festival seemingly with the purpose of reaffirming Laredo's American identity and membership. The Washington Birthday Celebration is a month long event. Part of this celebration includes the International Bridge Ceremony which takes place in the middle of the Lincoln-Juarez International Bridge right above the Rio Grande. The mayors from Laredo and Nuevo Laredo exchange their national flags (fig. 7). Other Mexican and U.S. dignitaries do the same. Four Abrazo (hug) Children are selected to represent Mexico and the 
United States, a boy and girl from each. They are dressed in regalia representative of their nation. They walk towards each other to exchange flags and embrace (fig 8). This interaction symbolizes the friendship, appreciation, and mutual respect shared by two nations. Gloria Anzaldua writes, "To survive the Borderlands you must live sin fronteras, (without borders) be a crossroads." My traditional Hispanic upbringing instilled an appreciation for Mexican culture. As a brown person growing up in the monoculture that is Laredo, I was surrounded by other Spanish speaking brown people. I was accustomed to speaking English at school and Spanish everywhere outside of school. Having never before left Laredo, I suddenly found myself visiting China in 2015 and then studying at West Virginia University. It didn't take long to realize that the people around me had experienced a far more Eurocentric education and a different form of upbringing. At several points, I became aware that I was one of few Hispanics, if not the first, that those around me had interacted with. This led to confusing new conversations. I was often asked about my ethnicity and told presumptive remarks like, "You speak English well”. Repeatedly, I was told that I didn't look American. As someone who grew up with the notion that the United States was a melting pot of cultures, I wondered why I was not seen as an American.

The 2016 presidential elections led to an increase in the stereotyping and fear of Mexicans. This negatively affected not only Mexicans, but Hispanics and Latinos. As part of his campaign, then-presidential-candidate Donald Trump proposed to build a wall at the border of the United States and Mexico. During his presidential announcement speech on June 26, 2015, he stated,

"When Mexico sends its people, they're not sending their best. They're not sending you. They're not sending you. [points out at crowd] They're sending people that have lots of

\footnotetext{
${ }^{1}$ Gloria Anzaldua, "To Live in the Border lands means you," in Infinite Division : An Anthology of Chicana Literature, ed. Tey Diana Rebolledo, and Eliana S. Rivero (Tucson: University of Arizona Press, 1993 ), 97.
} 
problems, and they're bringing those problems with us. They're bringing drugs. They're bringing crime. They're rapists."

By stereotyping Mexicans as rapists and criminals, support for the structure became more and more fervent. The negative views of Mexico along with these experiences led me to feel as a foreigner in my own country. The combination of wanting to feel welcome in my own country and wanting to educate others about the impact of their words led me to construct my work.

\footnotetext{
${ }^{2}$ Donald John Trump (speech, Donald Trump's Presidential Announcement Speech, Trump Tower, New York), June 16, 2015, accessed March 6, 2018, http://time.com/3923128/donald-trump-announcement-speech/.
} 


\section{BORDERS}

During my time in graduate school, I had the opportunity to travel to China and central Europe. I had the chance to see the Great Wall of China (fig. 9) and the Berlin Wall in Germany (fig. 10). While travelling from Vienna to Prague, I got to walk along the Iron Curtain Trail (fig. 11). Finding myself visiting structures on borders, I began to reflect on the border that I grew up on.

Over one third of Mexico's exports to the United Stated come over the border through Laredo. Minor fencing is currently in place on both sides of the Rio Grande (fig. 12). While inspection stations on the bridges have controlled the transportation of tangible goods, the Spanish language and Hispanic culture have always been part of Laredo's history. They are not imported.

Throughout the state of Texas, border patrol stations are located on the sides of highways, especially in areas closer to the border. All vehicles must pull over to these stations. While slowly driving forward, a photo of the vehicle is taken. A border patrol agent asks questions related to travel and if all people in the vehicle are citizens of the United States. For those who live in Laredo, the act of being questioned while traveling is the unavoidable norm. Border patrol agents know from training and experience that citizenship has no particular relationship to physical appearance or skin tone. If travelers are not citizens, they must have the proper documentation in order to continue with their journey. While the border patrol agent talks to the passengers, the license plate of the vehicle is being verified and dogs walk around the car sniffing for drugs, weapons, and stowaways. People and vehicles may be searched and/or confiscated/detained at any time for any given reason. 
The wall Donald Trump proposes to build at the United States-Mexico border has been controversial. The simplistic wall proposed would not significantly add to the extensive security along the border that already exists. The wall remains what it has been even from Trump's earliest mentions of it, a symbol of power. In his presidential announcement speech Trump says,

"I would build a great wall, and nobody builds walls better than me, believe me, and I'll build them very inexpensively, I will build a great, great wall on our southern border. And I will have Mexico pay for that wall."3

This was a convenient way to galvanize support from a majority-white conservative base with fears of low-cost immigrant labor and changing American cultural demographics during his campaign. As said by Margaret Hunter, "The maintenance of white supremacy in this country is predicated on the notion that dark skin represents savagery, irrationality, ugliness, and inferiority, and thus whiteness itself is defined by the opposite: civility, rationality, beauty, and superiority."4 Including "building a wall" in government rhetoric encourages profiling and discrimination against Hispanics by legitimizing xenophobic views. Unlike legitimate discussions of immigration, customs enforcement, and border security, the chant "Build the wall!" echoed in Trump's rallies. This idea of the wall was more than just a reaction towards Mexico. Trump mentions,

"They're sending us not the right people. It's coming from more than Mexico. It's coming from all over South and Latin America... but we don't know because we have no protection and we have no competence."

The wall is a simple concept, and a potent symbolic rejection of anything Hispanic/Latino as not-American. Having visited historically significant walls and researched other walls such as

\footnotetext{
${ }^{3}$ Donald John Trump (speech, Donald Trump's Presidential Announcement Speech, Trump Tower, New York), June 16, 2015, accessed March 6, 2018, http://time.com/3923128/donald-trump-announcement-speech/.

${ }^{4}$ Margaret L. Hunter, Race, Gender, and the Politics of Skin Tone (New York: Routledge, 2005), 2.

${ }^{5}$ Donald John Trump (speech, Donald Trump's Presidential Announcement Speech, Trump Tower, New York), June 16, 2015, accessed March 6, 2018, http://time.com/3923128/donald-trump-announcement-speech/.
} 
the Israeli Western Bank wall barrier, Walls of Babylon in Iraq, and Walls of Ston in Croatia, led me to believe that building a wall could be a way to start a conversation about issues on the border rather than “blocking” them. Heather Dalmage's article section Borders notes,

"Borders created to protect resources such as goods and power are kept in place by laws, language, cultural norms, images, and individual action as well as by interlocking with other borders including, national, religious, political, sexual, gender, racial, and age. Each has a unique history laden with power struggles. People are raised to understand their world through borders. We are taught from an early age to know where the borders exist. To young children, categories and their borders do not yet represent power and exclusion." 6

On October 2017, eight prototypes of the proposed wall were built near San Diego, California (fig. 13). I decided to construct a wall that would reference aspects of the prototypes. Artworks such as Grater Divide (fig. 14) and Expanded Expansion (fig. 15) have also inspired the development of this piece.

Nada Que Ver (Nothing to See) was made in five sections; each 12' tall, 2' wide, and 4" thick. Wood was used for the skeletal structure. Panels of $1 \frac{1}{2}$ " plywood were used to cover the front side of the wall. The panels were covered in joint compound so that the finished surface could resemble concrete. The back and sides of the wall were covered with masonite in order to create a smooth surface. After painting the wall a color that matched concrete, watered down concrete was patted on the front side of the wall to add more tonal variation to the surface. Loops of barbed wire were then attached to reference the prototypes and the "idea" of reinforcing security. The overall structure is $13^{\prime}$ tall and $10^{\prime}$ wide, looming in the corner of the gallery. The gray of the wall set the stage for a dismal and bleak experience when viewing the work.

\footnotetext{
${ }^{6}$ Heather M. Dalmage, "Mama, Are you Brown?: Multiracial Families and the Color Line" in Skin Deep: How Race and Complexion Matter in the "color-blind" Era, ed. Cedric Herring, Verna Marie Keith, and Hayward Derrick Horton (Chicago: University of Illinois Press, 2004), 84
} 


\section{MICROAGGRESSIONS}

In Race, Gender, and the Politics of Skin Tone, author Margaret Hunter states, "Most people of color will not end up in court over color bias, but all people of color will experience or witness unfair treatment because of a person's skin tone."” Dr. Derald Wing Sue defines microaggressions as, "the everyday verbal, nonverbal, and environmental slights, snubs, or insults, whether intentional or unintentional, that communicate hostile, derogatory, or negative messages to target persons based solely upon their marginalized group membership." ${ }^{8}$ Once away from home, microaggressions became a regular occurrence for me.

As expressed by Dalmage, "The "reading" of skin color and other discernible indicators of race guides most interactions." ${ }^{9}$ One afternoon, I went for a run in downtown Morgantown. I heard someone shout, "Go back to where you came from!" I turned my head to see a car speeding past me with five young men. They were strangers and I was alone. The threat of the experience was menacing and frightening. This particular example was more extreme and confrontational than the subtle, often-asked question of, "No, but where are you really from?" Responding, "Laredo, Texas" was apparently not an acceptable answer. This pointed question, along with the shouts from the car both suggested one thing, I was not part of "here" as in the United States, but rather "there" wherever there was.

It increasingly seemed that people associated a small range of skin tones with being "American." When attempting to explain how questions and comments such as these are

\footnotetext{
${ }^{7}$ Margaret L. Hunter, Race, Gender, and the Politics of Skin Tone (New York: Routledge, 2005), 2.

${ }^{8}$ Derald Wing Sue, "Microaggressions: More than Just Race," Psychology Today: , November 17, 2010, accessed March 2, 2018.

${ }^{9}$ Heather M. Dalmage, "Mama, Are you Brown?: Multiracial Families and the Color Line" in Skin Deep: How Race and Complexion Matter in the "color-blind" Era, ed. Cedric Herring, Verna Marie Keith, and Hayward Derrick Horton (Chicago: University of Illinois Press, 2004), 82.
} 
offensive, the person who made the comment was usually quick to excuse their words by saying they did not mean harm. Although intent was used as a way to diminish the impact, they were unaware of how often I experienced these microaggressions. Lorna Dee Cervantes writes, "I am marked by the color of my skin. The bullets are discrete and designed to kill slowly [...] my wounds: my stumbling mind, my 'excuse me tongue, and this nagging preoccupation with the feeling of not being good enough.' These bullets bury deeper than logic. Racism is not intellectual." 10

Trinidad Sanchez's poem Why am I so brown? had an impact on me by the time I was six. As stated in the poem, the title was a question often asked by young Chicana girls. As a child, I remember looking through a box of crayons and searching for the one labelled peach. Too young to understand how genetics works, I wanted my skin to be this color. During baths I would roughly scrub my skin with a loofah in hopes that it would become lighter. How much harder do I have to scrub so that I can become white? consists of several slip cast bars of soap (fig. 16). All of them are white except for one which is a medium beige similar to my skin tone. Recoger y Escoger, which translates to "collect and choose" consists of several different colored ceramic peaches (fig. 17). These peaches make reference to the color that I wanted to be.

Although I had long been used to getting questioned by Border Patrol when traveling, these social interactions were new to me and had not occurred in Laredo where "American" is a nationality, and not what some of the nation has come to consider it, an ethnicity. In Legal Alien, Pat Mora best phrases this experience as, “American but hyphenated, viewed by Anglos as

\footnotetext{
${ }^{10}$ Lorna Dee Cervantes, "How I, an Intelligent, Well-Read Person Could Believe in the War Between Races" in In Other Words: Literature by Latinas of the United States, ed. Roberta Fernández and Jean Franco (Houston: Arte Público Press, 1994), 38.
} 
perhaps exotic, perhaps inferior, definitely different." ${ }^{11}$ It was frustrating to know that I was not recognized as being an American. For a while, I was unsure of how I would discuss these issues in my work.

During previous semesters of graduate school, I attempted to address these issues with data I received from surveys I created. Similar to works by Charles Beneke (fig. 18), I attempted to use systems in order to make sense of my experiences. I began to contemplate where the line was drawn between light skin and dark skin, if one existed. Apparently, this edge is where I am. I created a survey that focused on the classification of skin tone. Two hundred people were asked to define thirty-three skin tone colors as either light or dark. Surface Tension (fig. 19) is the visual representation of the results collected from that survey.

After meetings with my faculty, I came to the conclusion that by taking a personal approach to my work, I as an artist would be able to share my experiences more effectively. Agnes Martin wrote, "It is commonly thought that the intellect is responsible for everything that is made and done. It is commonly thought that everything that is can be put into words. But there is a wide range of emotional response that we make that we cannot put into words." 12

As a part of the art, I give a visual presence to xenophobic comments and how easily they are overlooked. I call the viewers' attention to the normalization of the microaggressions by having the ones that have been told to me hand-written on square pieces of paper on the back side of Nada Que Ver (fig. 20). By having each paper the same size and placed at the same height, each of these phrases, no matter the intent, are equal.

\footnotetext{
${ }^{11}$ Pat Mora, "Legal Alien," in Infinite Divisions : An Anthology of Chicana Literature, ed. Tey Diana Rebolledo, and Eliana S. Rivero (Tucson: University of Arizona Press, 1993), 95

12 Agnes Martin, "Beauty is the Mystery of Life" in Uncontrollable Beauty: Toward a New Aesthetics, ed. Bill Beckley (New York: Allworth Press, 1989), 401.
} 
The following is a list of comments that have been said to me that were used for this installation.

1. Coming from an educated background, I just don't seem to understand your work.

2. So like, what are you?

3. They are lazy and don't want to contribute.

4. Oh, it's because you're Mexican.

5. You speak English well.

6. Go back to where you came from!

7. But don't you think they are trying to steal our jobs?

8. So how long have you been in America?

9. You don't act like a Latina.

10. Hispanic, Mexican, Latino, they're all the same.

11. You don't look American.

12. But where are you really from? 


\section{CACTI}

Laredo, Texas consists of flat land and a semi-arid climate of little rain and very high temperatures. Those plants that manage to grow in this environment are short and evolved to preserve water rather than to grow tall in competition for sunlight. The shortest and most resilient of the native plants are the cacti, life that is adapted specifically to hostile environments. Known for their ability to sustain and thrive in harsh climates, cacti are a symbol of endurance in Hispanic culture. The poem Desert Women best encompasses this view,

$$
\begin{gathered}
\text { "Desert women know } \\
\text { about survival. } \\
\text { Fierce heat and cold } \\
\text { have burned and thickened } \\
\text { our skin. Like cactus } \\
\text { we've learned to hoard, } \\
\text { to sprout deep roots, } \\
\text { to seem asleep, yet wake } \\
\text { at the scent of softness } \\
\text { in the air, to hide } \\
\text { pain and loss by silence, } \\
\text { no branches wail } \\
\text { or whisper our sad songs } \\
\text { safe behind our thorns. } \\
\text { Don't be deceived. } \\
\text { When we bloom, we stun."13 }
\end{gathered}
$$

One of my first experiences seeing ceramics not as pottery but as sculpture was during my undergraduate years. The library building included a gallery space that replicated the studio of ceramic artist Helen Richter Watson, a native of Laredo, Texas. Her large biomorphic sculptures were abstractions of cacti (fig. 21). These sculptures were then marked with black to suggest shadows. 2017 NCECA emerging artist, Christina Erives’s piece Sin Titulo (fig. 22) was

\footnotetext{
${ }^{13}$ Pat Mora, Nepantla: Essays from the Land in the Middle (Albuquerque: University of New Mexico Press, 1993), 67-68.
} 
an installation of cacti. The cacti were all the same shade of green and were very flat. These two artists had two very different interpretations of cacti both made from clay. I would go on to create cacti of my own.

Clay, as a malleable medium, was chosen to render different species of cacti found along the border of Laredo, Texas and Nuevo Laredo, Tamaulipas. A combination of wheel throwing, pinching, slab building, and coiling was used to construct the cacti. I chose to reference prickly pear and barrel cacti of the genus opuntia, mammallaria, and ferocactus. These cacti grow on both sides of the border. Their spikes were created by pushing nails into the wet clay before bisque firing them. A combination of slip, stain, glaze, and watered-down paint was used to treat the surface of each cactus. Although there is a system to the placement of the nails and the patterned texture of the cacti's surface, the organic quality of the form and the intentional irregularities of the nails make for sculptures that heavily reference and generalize types of cacti without simply being recreations of them (fig. 23). As with the cacti, generalizations and assumptions are made about Hispanics, whether it is about their appearance, occupation, or knowledge of language. The cacti in contrast to the wall are small and numerous. Though visually threatened by the wall, the concept of limiting or confining the natural range of cacti with an artificial structure is useless. Similarly, the proposed wall at the border functions with the same futility. 


\section{EXHIBITION}

At the foot of the ramp leading from the vestibule to the gallery, I left written instructions guiding the audience to walk straight forward around the installation. jAguas! (Waters!), was assembled in various clusters, referencing how cacti grow, to take up the central space of the gallery. Each cluster was surrounded by sand, which made the cacti seem as if they were growing up out of the gallery floor. The various sizes of the cacti and their arrangement in clusters suggests anthropomorphic families. Similar to artist Antony Gormley, (b. 1950) who uses his sculptures to dictate the path of the audience in his piece Field Project (fig. 24), I used the sand to create a barrier between the audience and the work leaving only enough space to walk at the edge of the gallery.

Standing opposed to the cacti is Nada Que Ver, a barbed-wire-topped wall so tall as to overwhelm both the cacti and the viewer. The diminutive size of the cacti in relationship to the wall speaks to a sense of defiance, perhaps even futile defiance, in the face of proposed developments along the border. The modest scale of these lumpy forms with their sharp spikes speaks to their resilience. Although there is a difference in scale, structure, and nature, the wall and cacti are both heavy and suggest immovability.

Nada Que Ver was positioned at the back left-hand corner of the gallery. The bottom of the wall was also surrounded by sand. The gallery's left wall and half of the back wall were painted to match Nada Que Ver, acting as an extension of that wall. As the audience walks towards the back right corner of the gallery, they see a work light hung from the gallery wall behind Nada Que Ver. This light acts as an indicator letting the audience know that there is more to view behind the wall. As they walk closer, the viewer experiences the scale of the wall. In 
presenting an exhibition that combines a referenced landscape with a wall acting as a division, I create an interior and exterior space. As Bachelard mentions, "Outside and inside form a dialect of division. Philosophers, when confronted with outside and inside, think in terms of being and non being." 14 In a similar regard, "here" and "there" are two places divided by this structure. While the terms "inside" and "here" are understood as very limited spaces, the terms "outside" and "there" are understood to be vast. I force each viewer to confront this wall without knowing whether I am a proponent or opponent of the proposed structure until they walk behind it. The back side of the wall has twelve 4" 4 " gray pieces of paper, the same color as the wall, hung in a horizontal line. On these sheets of paper are the insulting comments that I have been told while away from my home. The work light provides enough light for people to read these papers while still keeping this area dim.

One literary work worth mentioning is "The Poetics of Space." Several chapters further informed my choice of position for the wall.

"...every corner in a house, every angle in a room, every inch of secluded space in which we like to hide, or withdraw into ourselves, is a symbol of solitude for the imagination... The corner becomes a negation of the Universe. When we recall the hours we have spent in corners, we remember above all silence, the silences of our own thoughts. The corner is a haven that ensures us one of the things we prize most highly-immobility... The corner is a sort of half-box, part walls, part door. It will serve as an illustration for the dialects of inside and outside."15

By assembling an installation composed of sculptural objects, the audience is immersed in the exhibition. I wanted my work to focus on a specific location while also addressing the feeling of being "out of place" that I experienced when leaving Laredo. Con el Nopal en la Frente references the landscape at the border of southwest Texas and Mexico. As Guy Brett

\footnotetext{
${ }^{14}$ Gaston Bachelard, The Poetics of Space, trans. M. Jolas (Boston: Beacon Press, 1994), 212.

${ }^{15}$ Gaston Bachelard, The Poetics of Space, trans. M. Jolas (Boston: Beacon Press, 1994), 136-137.
} 
mentions, "One way of tracking the relationship between art work and reality, would be through the metaphor of 'place'...the artistic work itself could be understood as a dialect of placement/displacement." ${ }^{\text {16 }}$ In this way, the work suggests an exterior place within an interior space.

${ }^{16}$ Archer, Michael, Guy Brett, and Catherine De Zegher. Mona Hatoum. (London: Phaidon, 1997), 34. 


\section{WORDS AND IMAGERY}

I am able to give inference to the area that the installation references and my own personal opinions of the political situation by making a connection between words and imagery. The title of the show and of each of the works are Spanish slang phrases that are common along the Texas-Mexico Border. The literal translation of each of these titles is just as relevant to the piece as their connotations.

Con el Nopal en la Frente is an expression used in Hispanic culture that translates to "with a cactus on your forehead." This expression is used to describe someone who cannot deny something that is so obvious. It is often used as a reaction when someone who is Mexican or of Mexican descent is trying to act as "Americanized" as possible only to have physical features dictate their identity. This also further relates to the land that has to be crossed in order to get from Mexico to Texas.

¡Aguas! translates to "waters" but is usually shouted when telling someone to watch out, and so it is a well-suited, yet ironic phrase for a field of sharp cacti.

Nada Que Ver translates to "nothing to see." The wall blocks what is behind it leaving the viewer with nothing to see. Nada Que Ver actually has several meanings such as "that's nonsense", "this has nothing to do with the issue", or "no, you're wrong", depending on how it is being used. This phrase gives a description as to what the wall is doing but also reveals my personal take on it. 


\section{SOCIAL ENGAGEMENT}

To create a dialogue with the viewer, I offer an experimental space where they can participate by bringing in their own experiences as an extension of Nada Que Ver. Ila Sahai Prouty's Paper Bag Test (fig. 25) informs my method of achieving an interactive piece. Through this approach I use my personal experiences as a way to begin a conversation with the audience. During the reception, only six to eight people were allowed to be in the gallery at once. By limiting the noise level in the gallery, the space allowed for contemplation without much of the distraction that usually happens during receptions that were made for socializing.

All viewers were given the opportunity to participate in the exhibit. As people waited in line to come into the gallery, each person was handed a 4"x4" gray paper, similar to those that had been used behind the wall. Each paper had instructions and a piece of Velcro. Each viewer was asked to write down something said to them that they found to be insulting but was not meant to be. By questioning the viewer before they were even allowed into the gallery, I put the audience in a situation similar to the process of being questioned by border patrol when travelling within Texas. Once the viewer was allowed in the gallery and had walked through the space, they were able to place their sheet of paper onto the Velcro that had been attached to the left wall of the gallery prior to the reception. Ninety people participated (refer to Appendix B). Their responses addressed a variety of issues such as beauty standards, sexism, racism, and sexuality (fig. 26). Several members of the audience returned to the gallery to see what others had written. These written comments from the audience allowed the viewer to learn not only from me, but from each other. 
This exhibition contained two main works but was experienced by the viewer in two ways, as a viewer and a participant. As said by Meyer Schapiro, “...we do not see all of a work when we see it as a whole. We strive to see it as completely as possible and in a unifying way, though seeing is selective and limited." 17

${ }^{17}$ Meyer Schapiro, "On Perfection, Coherence, and Unity Form and Content" in Uncontrollable Beauty: Toward a New Aesthetics, ed. Bill Beckley (New York, NY: Allworth Press, 1989), 12. 


\section{INFLUENCES}

Identifying my own motives, and enhancing the presentation of my work were things discovered simultaneously with making. Understanding my work also came from researching art that is a commentary on politics as well as individual artists investigating similar subject matter.

Mona Hatoum's Grater Divide was helpful as I was making my own wall. Her large sculpture not only suggested divisions, but her choice of title in relationship to the sculpture linked visual imagery with language. Born in Palestine, Hatoum examines displacement and the politics in her homeland. Judy Chicago's The Dinner Party only allows for the audience to walk around the outside of the work and I guided my viewers in a similar way (fig. 27). This evokes the idea of exclusion by creating a space that each viewer is allowed to see but cannot access. Christine Sun Kim's use of sound in her work was beneficial when trying to set the ambience of the gallery during the reception (fig. 28). As someone who is deaf, Kim uses sound in her work as a means of addressing her disconnect from sound as most people experience it. Adrian Piper demonstrated a simple yet effective use of text. In My Calling (Card) \#1 Piper uses text as a way to inform another person that they have said something racist (fig. 29).

With Donald Trump as President, these preexisting issues have now been brought to the surface. Over the last two years, there has been an increase in politically motivated art and activism within the Hispanic community. Daniela Madrigal's exhibition I Came from Wet explored the challenges that immigrants face in pursuit of the "American Dream". She obscured text within her works (fig. 30). Teresita de la Torre found a shirt on the border in the California desert. She wore the shirt every day for a year and documented her journey for the duration of this work titled Todos los Dias, which translates to "Everyday" (fig.31 and fig. 32). Madrigal, de 
la Torre, and several other young artists have been making a connection with viewers by using their own personal experiences and combining them with the stories of others. I wanted to do something similar by allowing my viewers the opportunity to share their experiences. 


\section{CONCLUSION}

Con el Nopal en la Frente gives visual presence to the microaggressions that are often excused and overlooked. My thesis exhibition served as an investigation of my personal experiences drawn from the interactions upon leaving home. I came to the realization that my art is an extension of my experiences and a reaction to my surroundings. By using current political issues to start a conversation, my hope is that the audience is able to gain a greater understanding of how words, even if not meant to be malicious, can be insulting. 


\section{FIGURES}

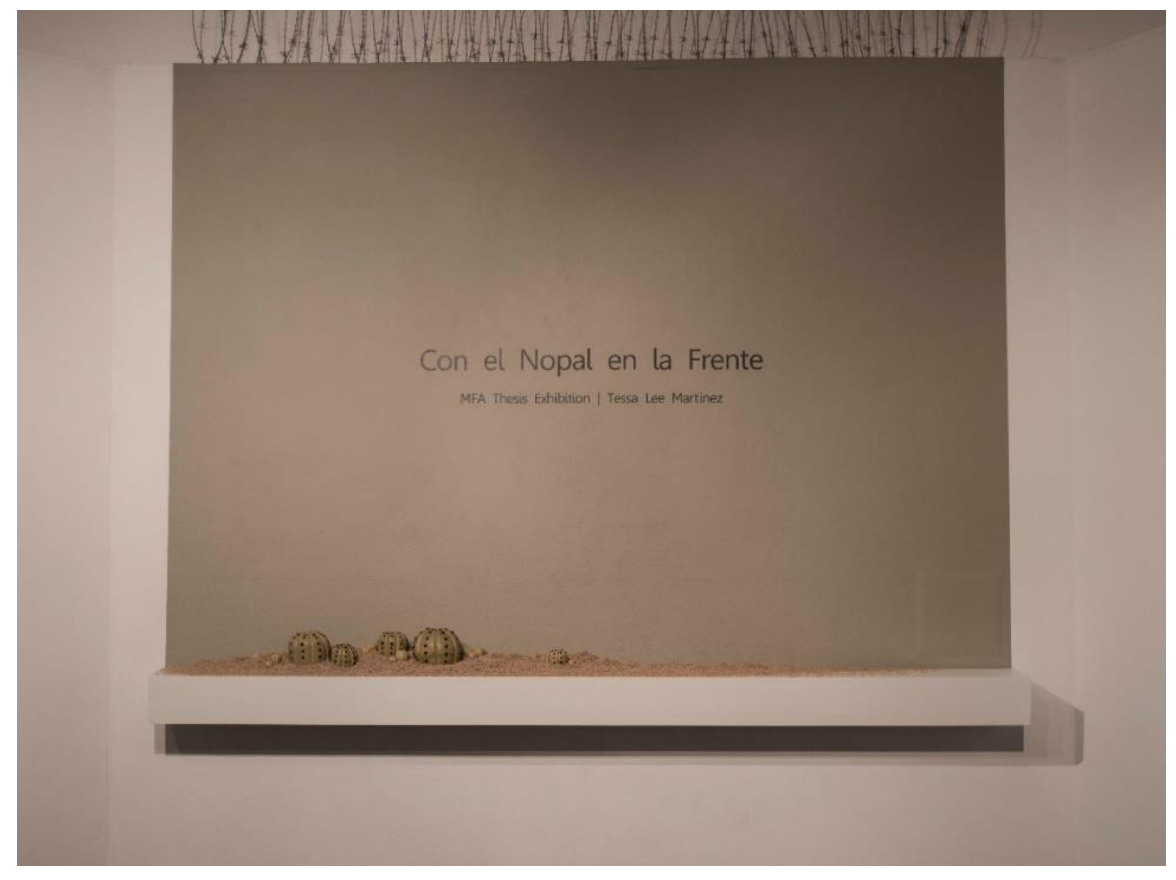

Figure 1. Tessa Lee Martinez, Con el Nopal en La Frente (vestibule), 2018.

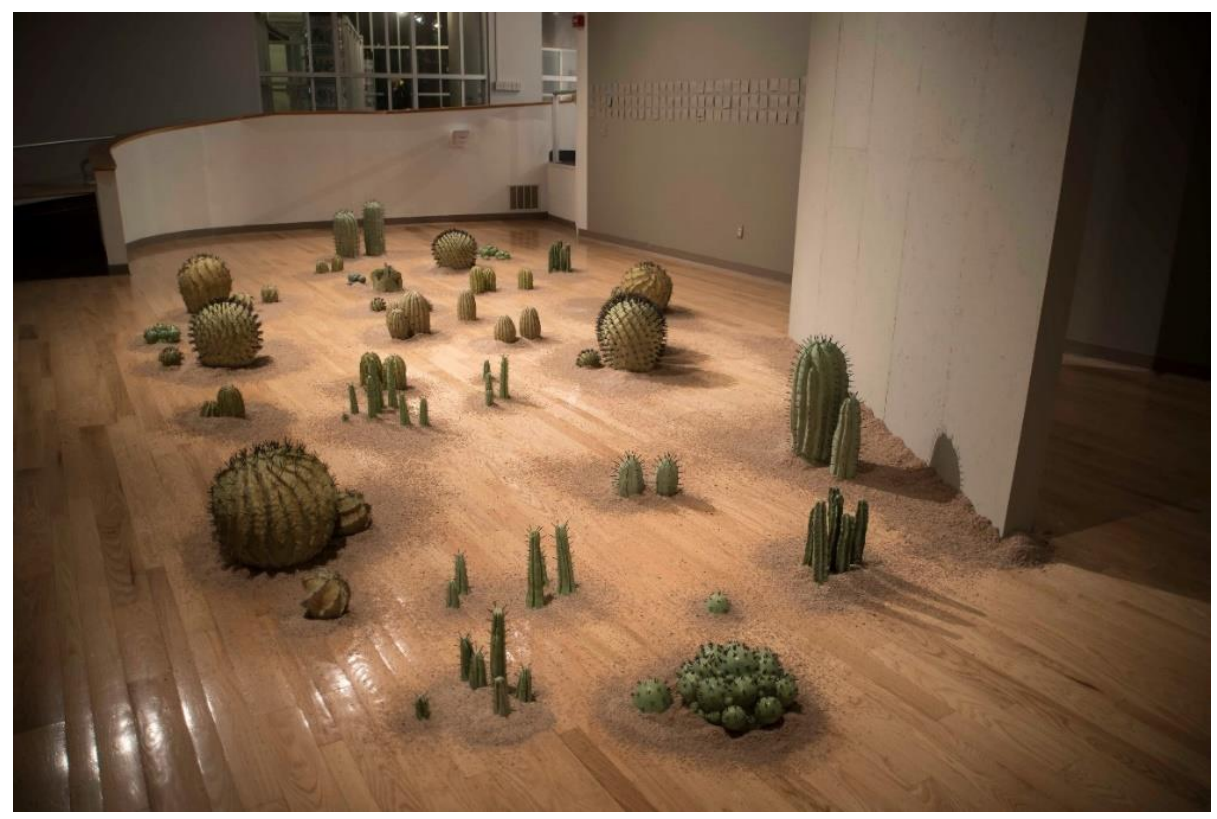

Figure 2. Tessa Lee Martinez, ¡Aguas!, 2018, ceramics and mixed media. 


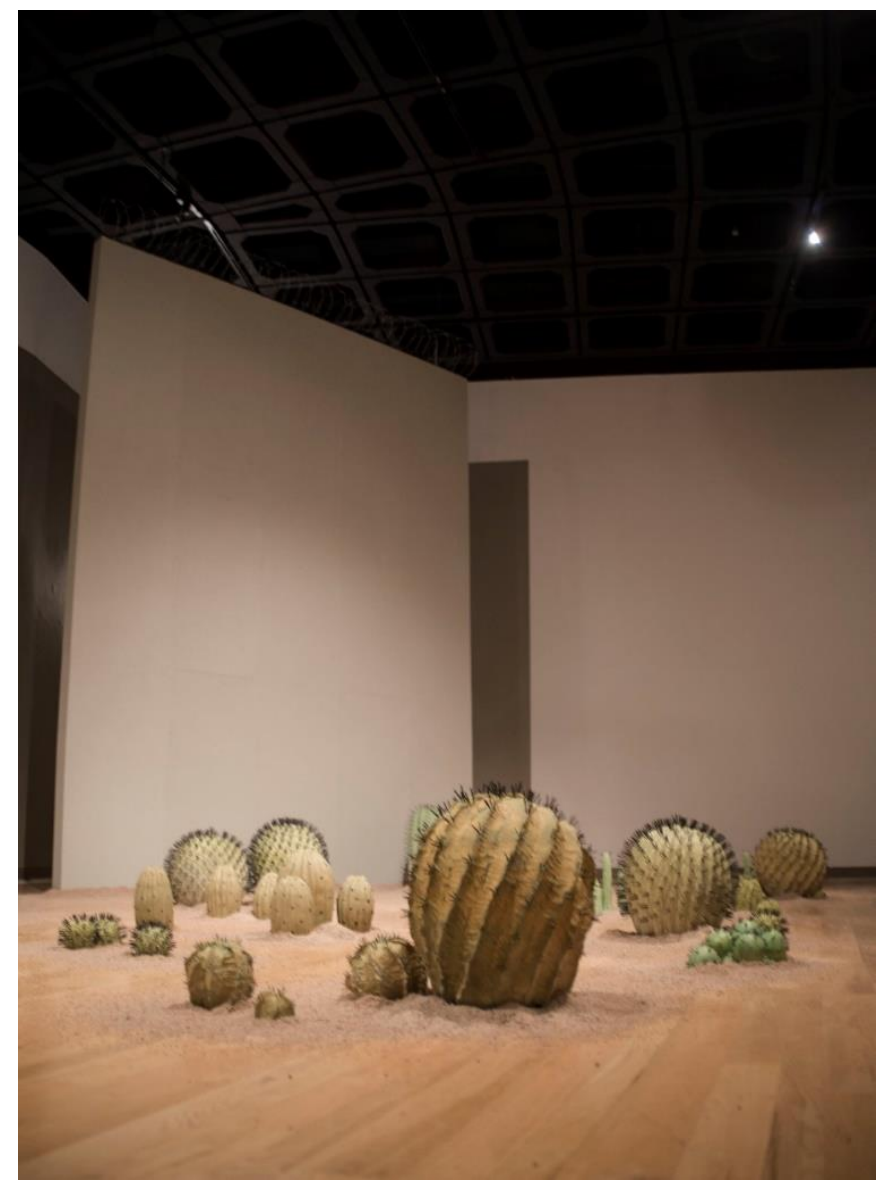

Figure 3. Tessa Lee Martinez, Nada Que Ver, 2018, wood, masonite, joint compound, barbed wire, concrete, paint, paper, sharpie pen.

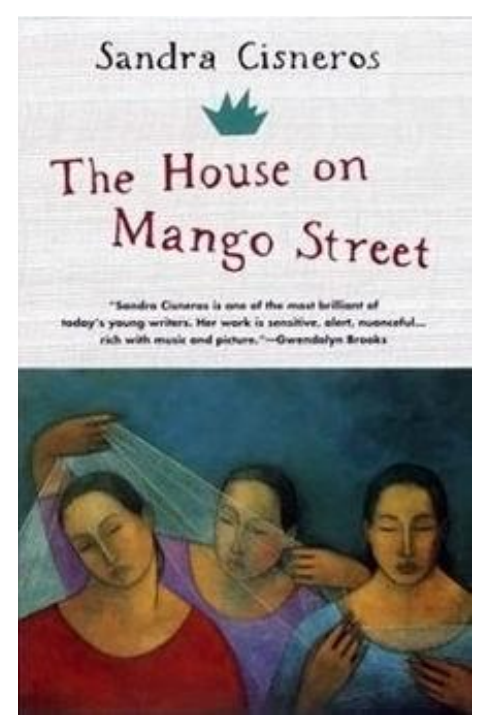

Figure 4. Sandra Cisneros, The House on Mango Street, 1984. Reproduced from https://en.wikipedia.org/wiki/The_House_on_Mango_Street (accessed on March 28, 2018). 


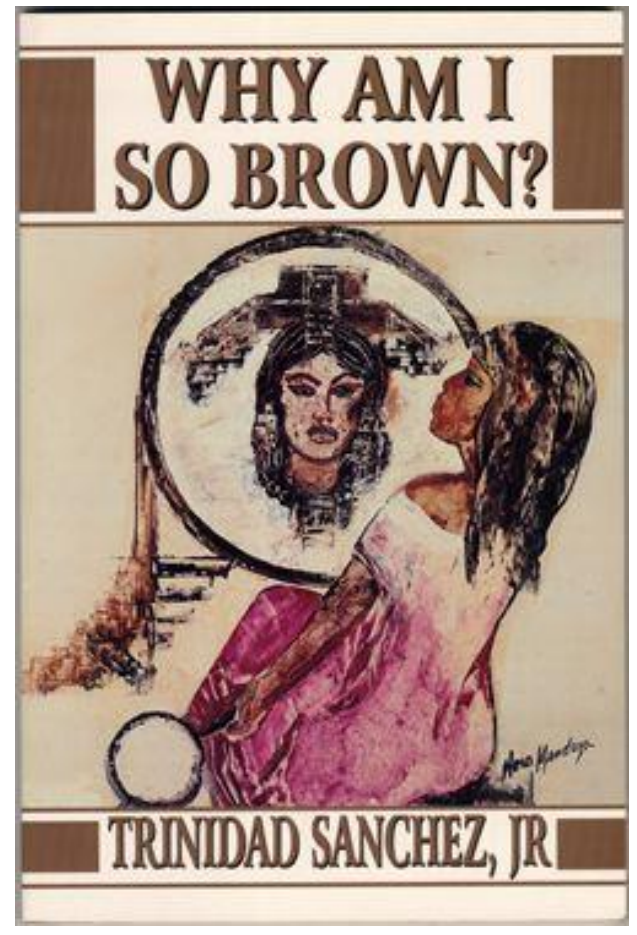

Figure 5. Trinidad Sanchez, Jr. Why am I so Brown?, 1991. Reproduced from https://labloga.blogspot.com/2010/10/hanging-out-with-mr-raza-and-trinidad.html (accessed March 23, 2018).

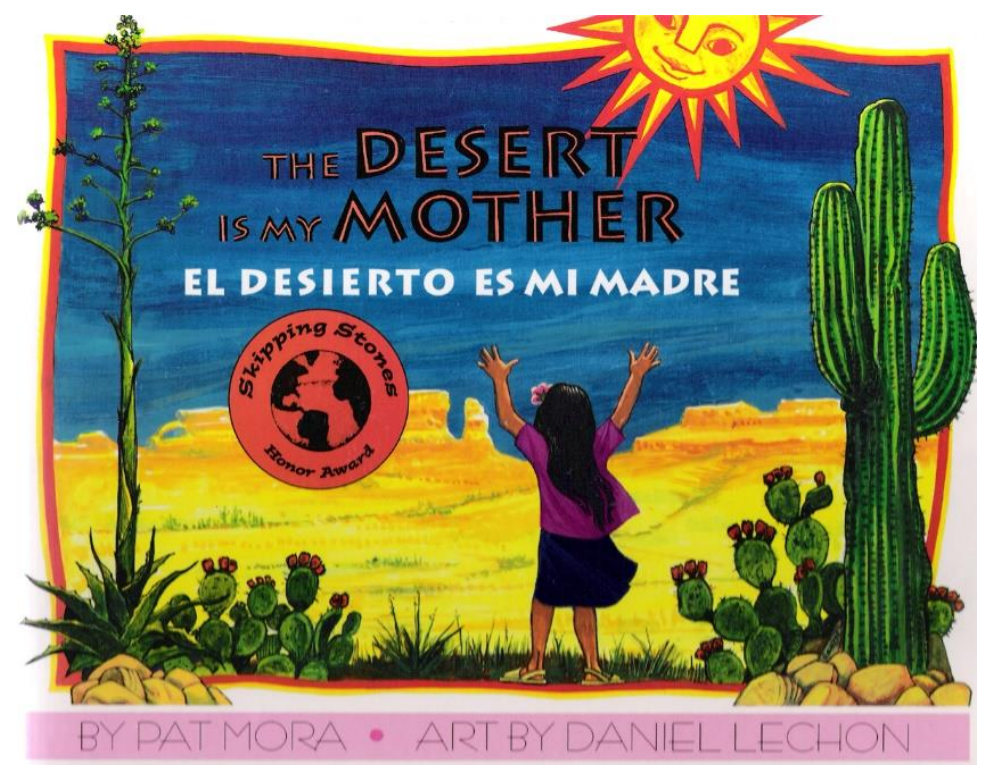

Figure 6. Pat Mora, The Desert is my Mother, 1994. Reproduced from http://www.patmora.com/books/the-desert-is-my-mother/ (accessed March 25, 2018). 


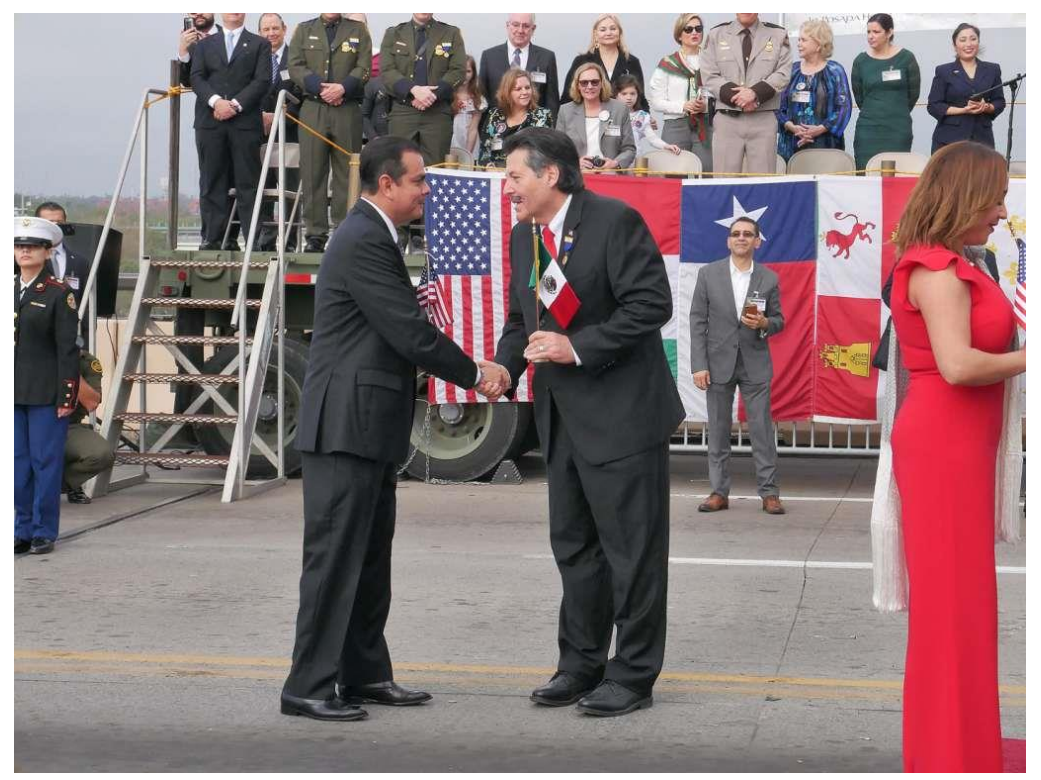

Figure 7. Cuate Santos, Mayors Exchanging Flags at International Bridge Ceremony, 2018. Reproduced from https://www.lmtonline.com/galleries/slideshow/Photos-2018-AbrazoCeremony-at-Juarez-Lincoln-178638/photo-15096110.php (accessed April 1, 2018).

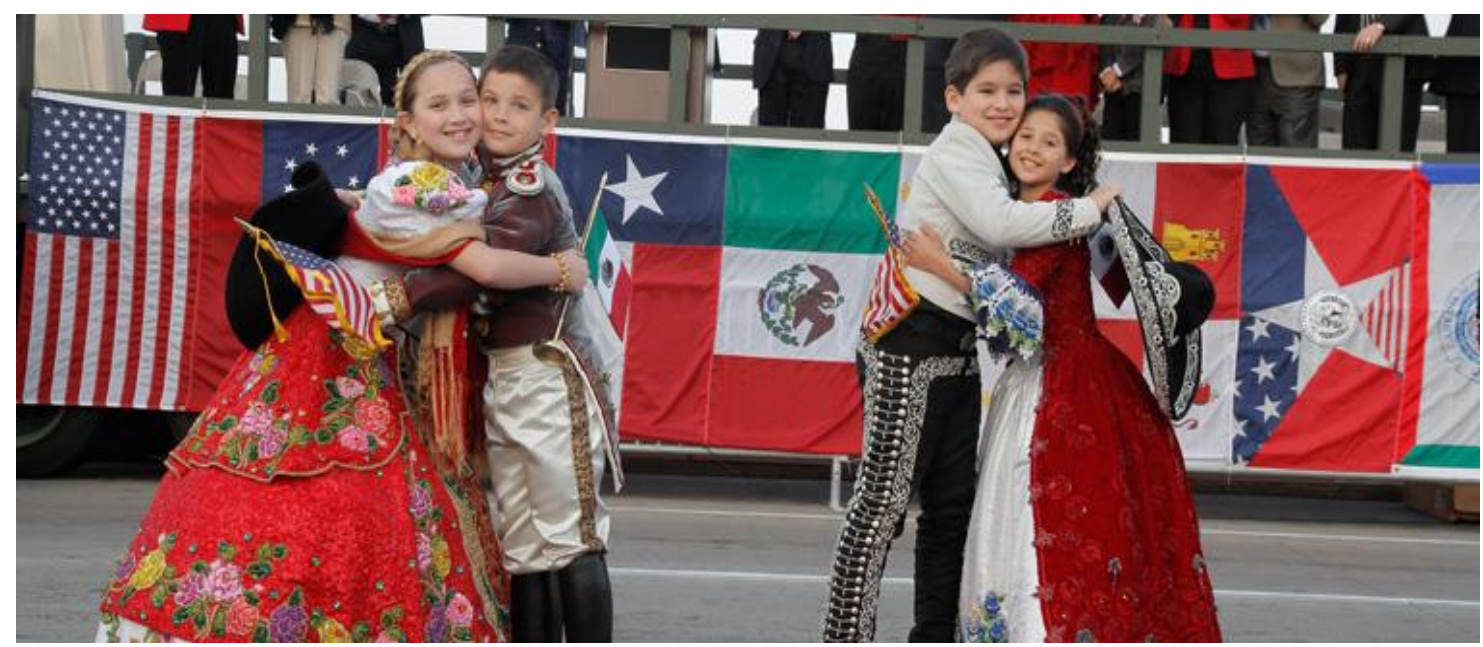

Figure 8. Abrazo Childen, 2017. Reproduced from http://www.wbcalaredo.org/event/international-bridge-ceremony-sponsored-by-la-posada-hotel/ (accessed April 3, 2018). 


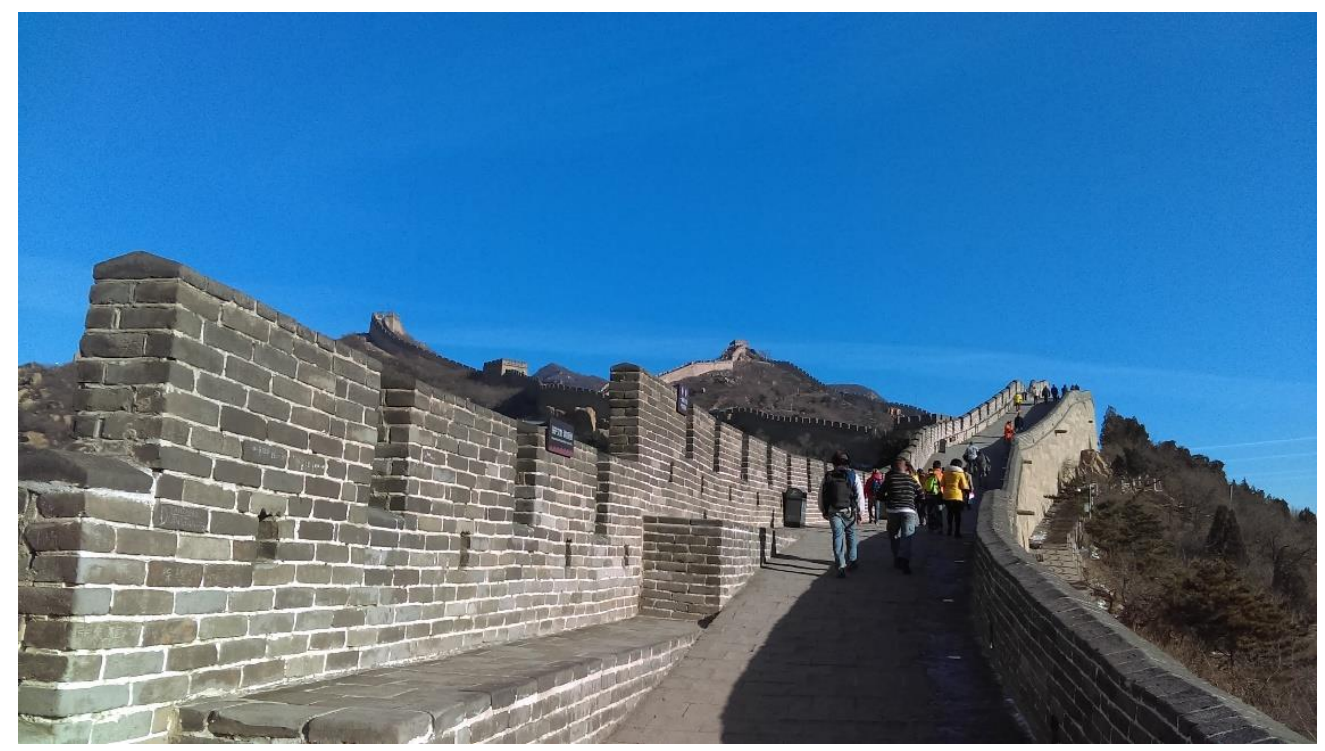

Figure 9. Great Wall of China, 2015 (personal photo).

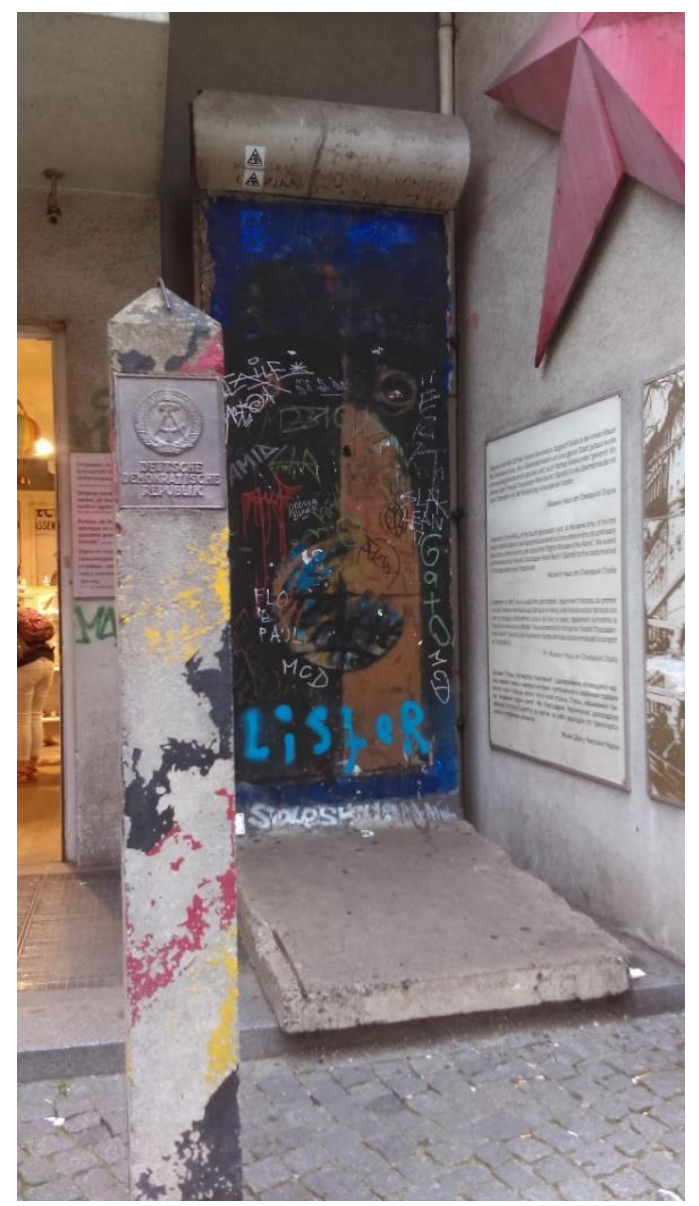

Figure 10. A portion of the Berlin Wall at the entrance of the Checkpoint Charlie Museum, 2017 (personal photo). 


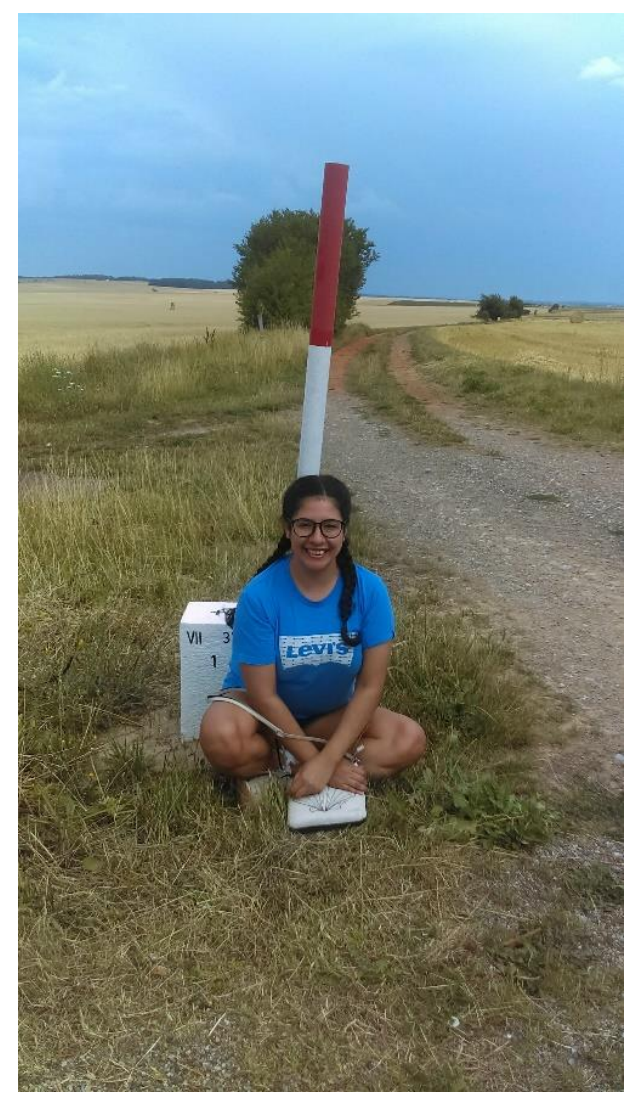

Figure 11. Iron Curtain Trail at the border of Austria and Czech Republic, 2017 (personal photo).

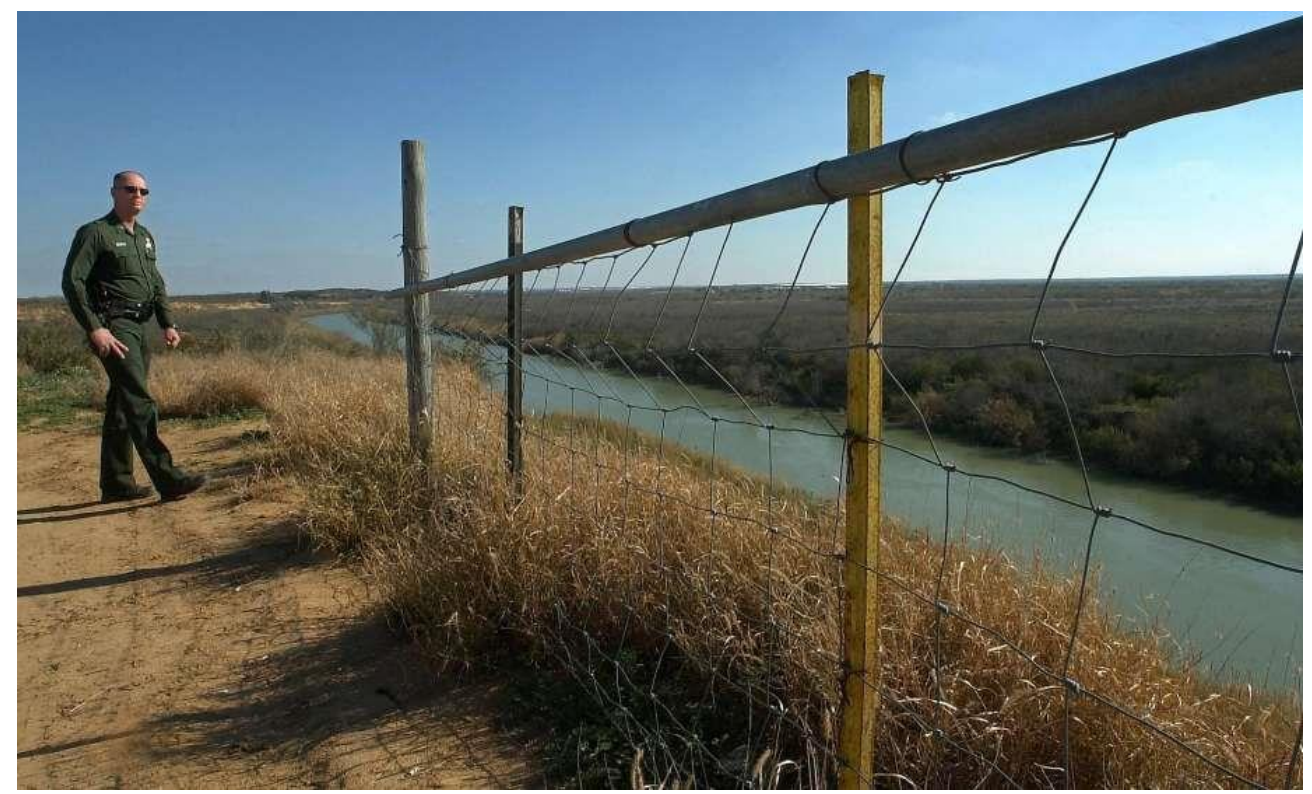

Figure 12. U.S. Border Patrol agent Gregory Bull looks out over the Rio Grande River near Laredo, Texas, 2011. Reproduced from https://www.Imtonline.com/local/crime/article/BorderPatrol-Murderer-child-molester-arrested-12198420.php (Accessed April 5, 2018). 


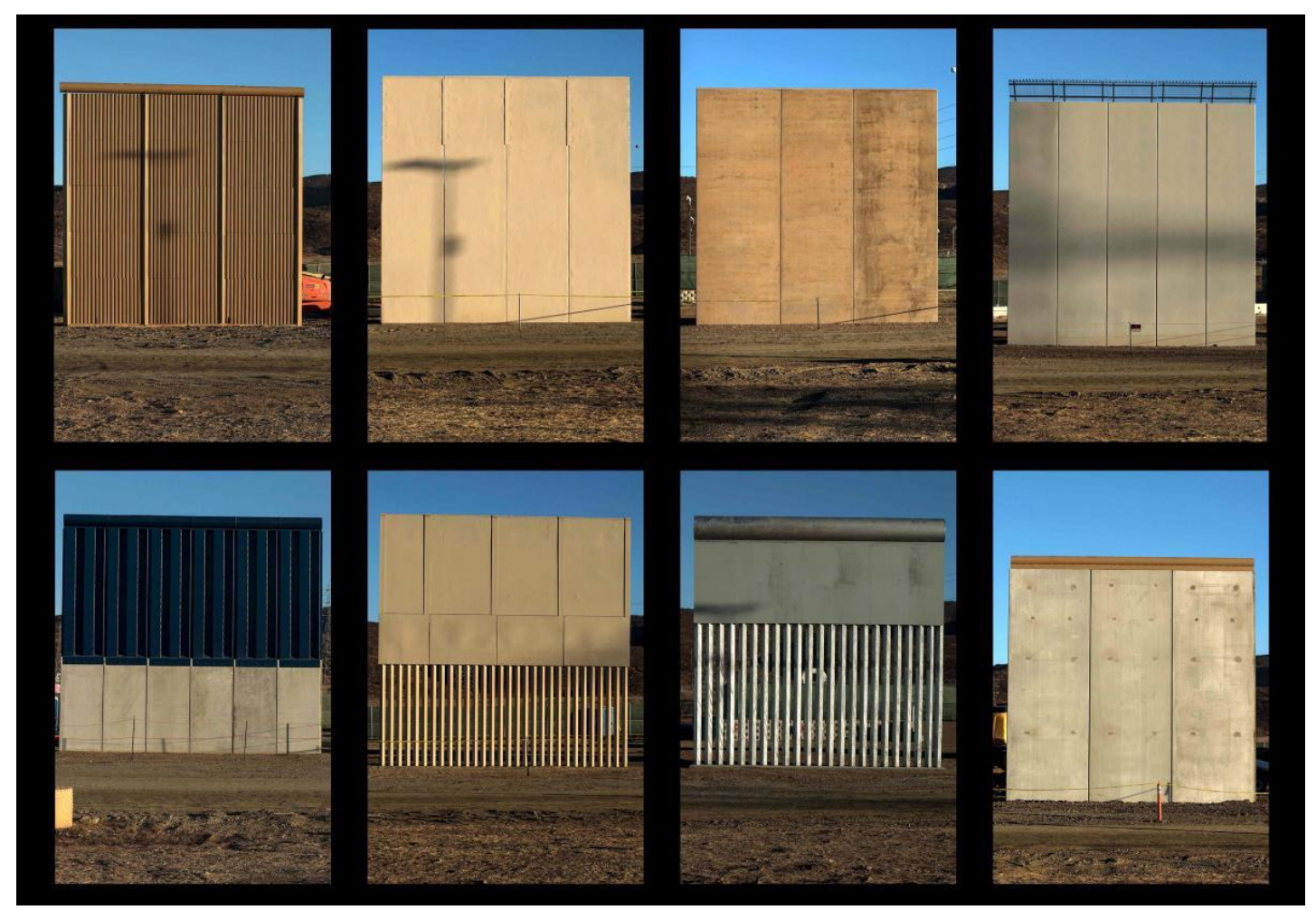

Figure 13. Wall Prototypes in San Diego, California, 2017. Reproduced from http://www.nydailynews.com/news/construction-underway-us-mexico-border-wall-prototypesgallery-1.3558988?pmSlide $=1.3582751$ (Accessed January 18, 2018).

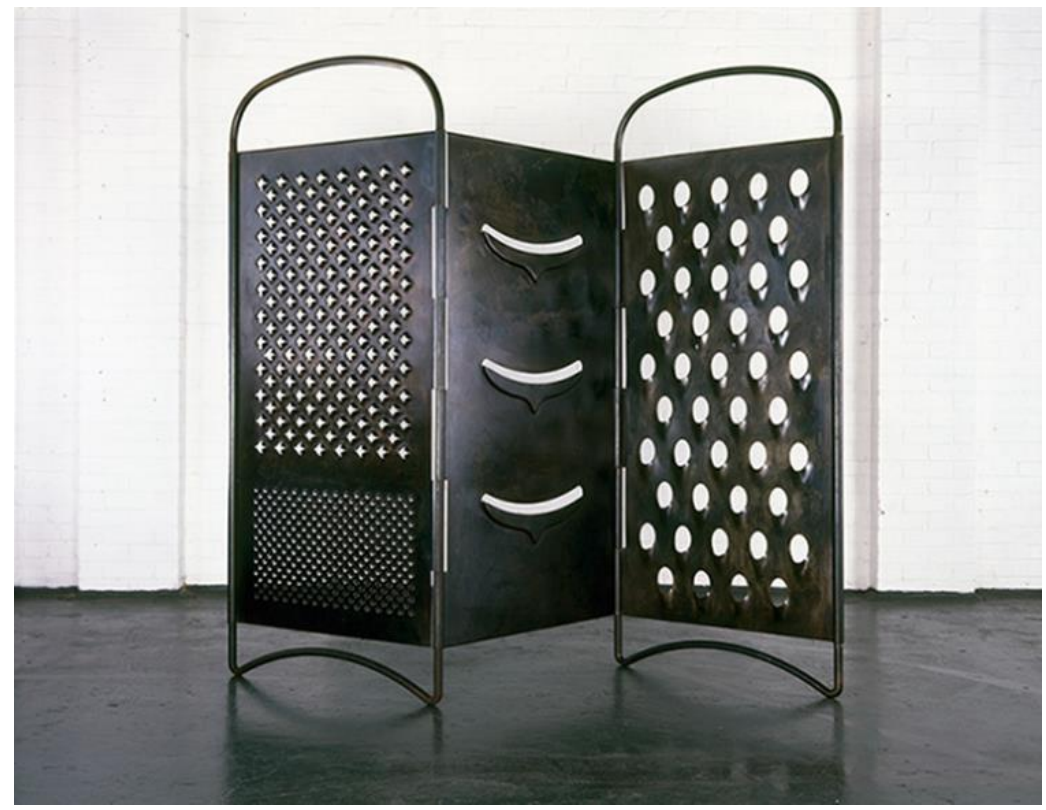

Figure 14. Mona Hatoum, Grater Divide, 2002, mild steel. $204 \mathrm{~cm}$ x $3.5 \mathrm{~cm}$ x variable width. Reproduced from https://hyperallergic.com/317968/the-chilling-anxious-world-of-mona-hatoum/ (accessed October 15, 2017). 


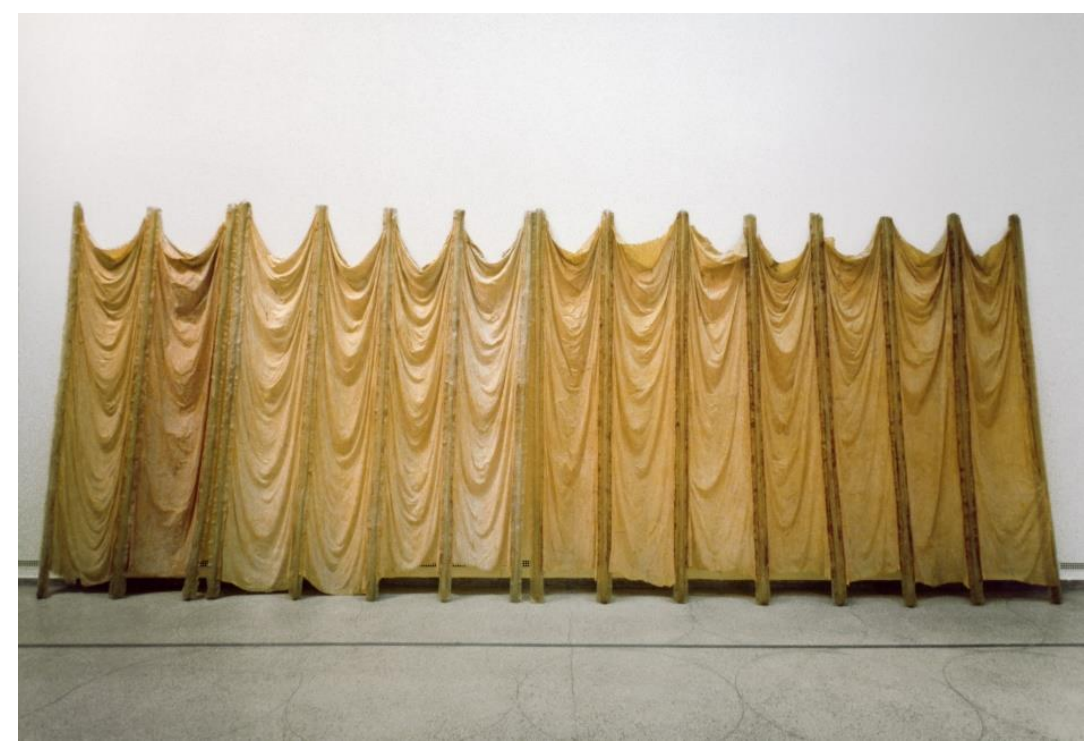

Figure 15. Eva Hesse, Expanded Expansion, 1969, fiberglass, polyester resin, latex, and cheesecloth. 10ft 2 in x $25 \mathrm{ft}$ overall. Reproduced from https://www.guggenheim.org/artwork/1648 (accessed October 17, 2017).

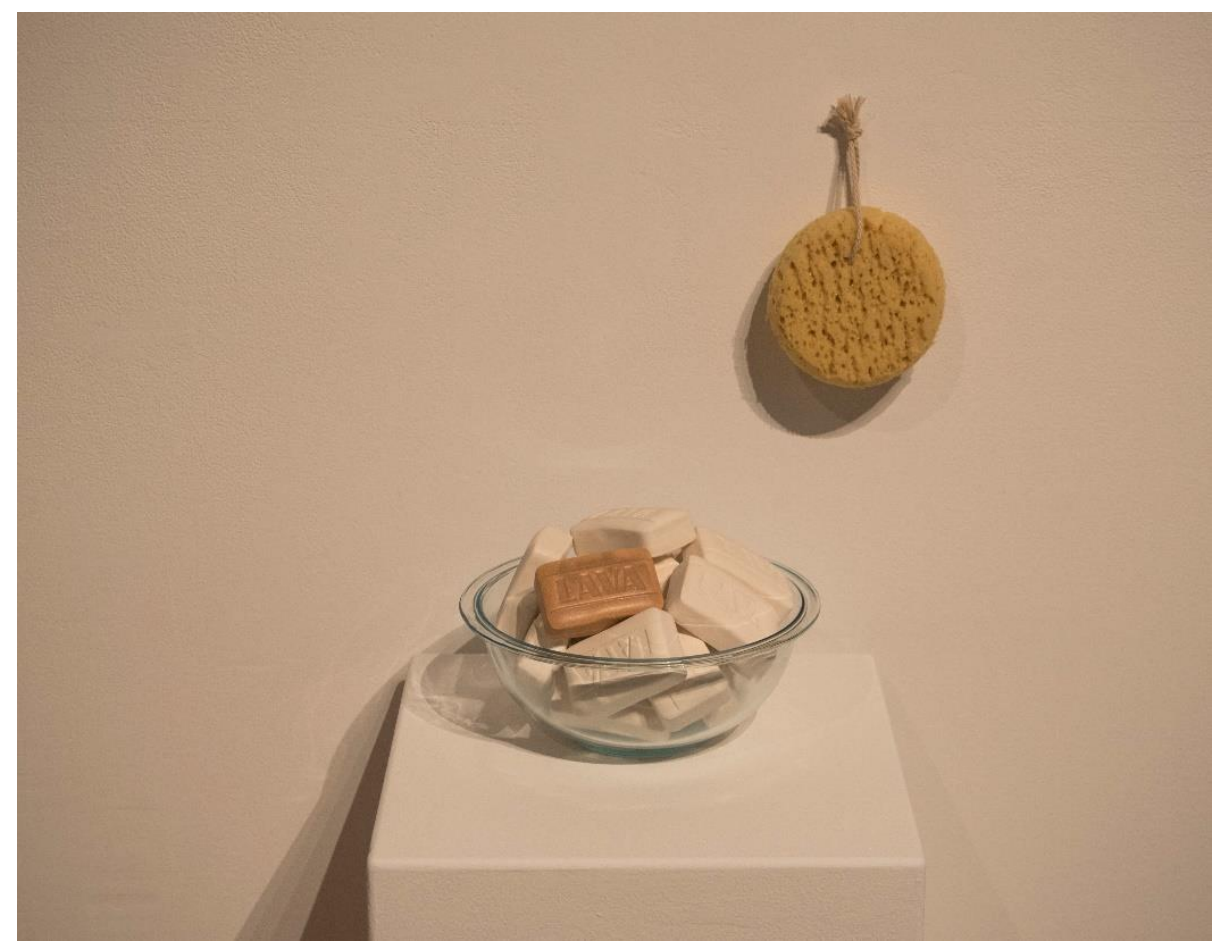

Figure 16. Tessa Lee Martine, How much harder do I have to scrub so that I can become white?, 2017, slip cast earthenware, bowl, loofah, 12in x12in x16in. 


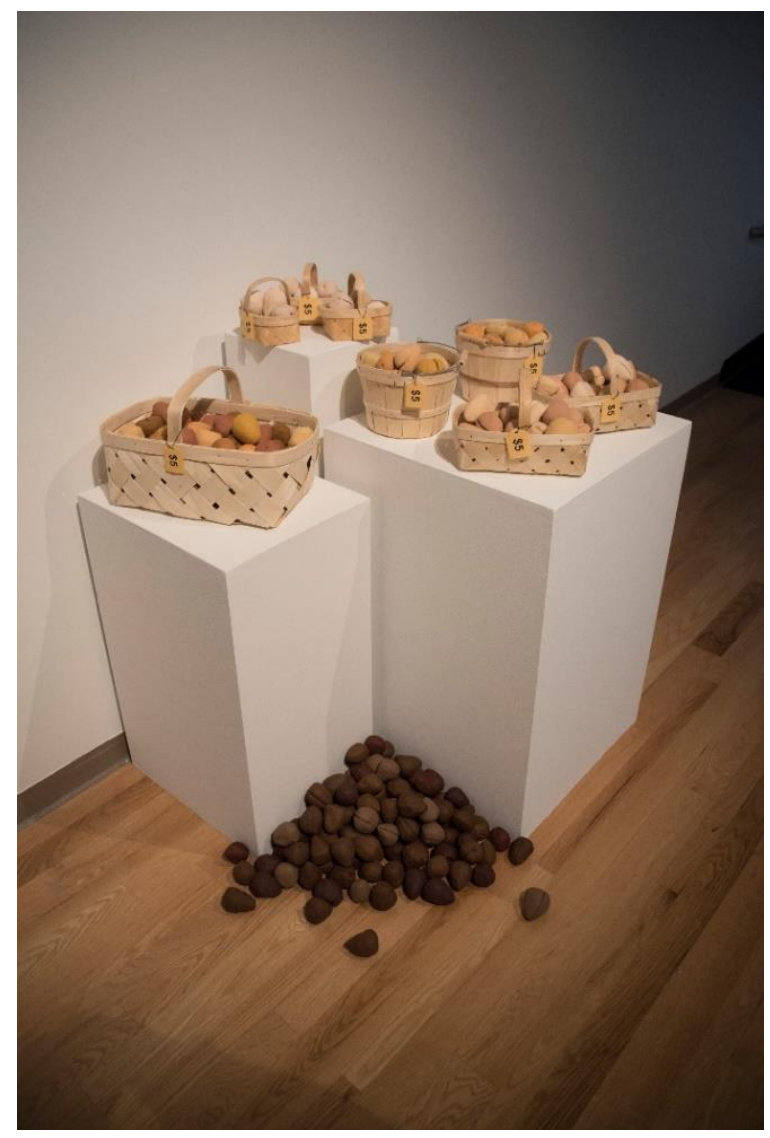

Figure 17. Tessa Lee Martinez, Recoger y Escoger, 2017, ceramic, paint, baskets, dimensions vary.

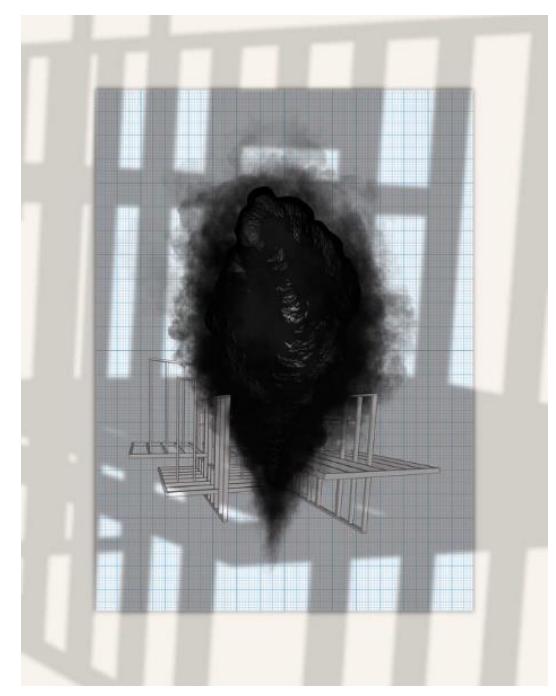

Figure 18. Charles Beneke, Disruption: This is Real, 2017, inkjet and chine collé, 28in x 22in. Reproduced from https://www.charlesbeneke.com/in-absence-of-reason/2018/1/31/disruptionbe-still-kknd9-nwced-gw9k9-a9lbr-62 gnr-6pjyc-cjm8f (accessed April 9, 2018). 


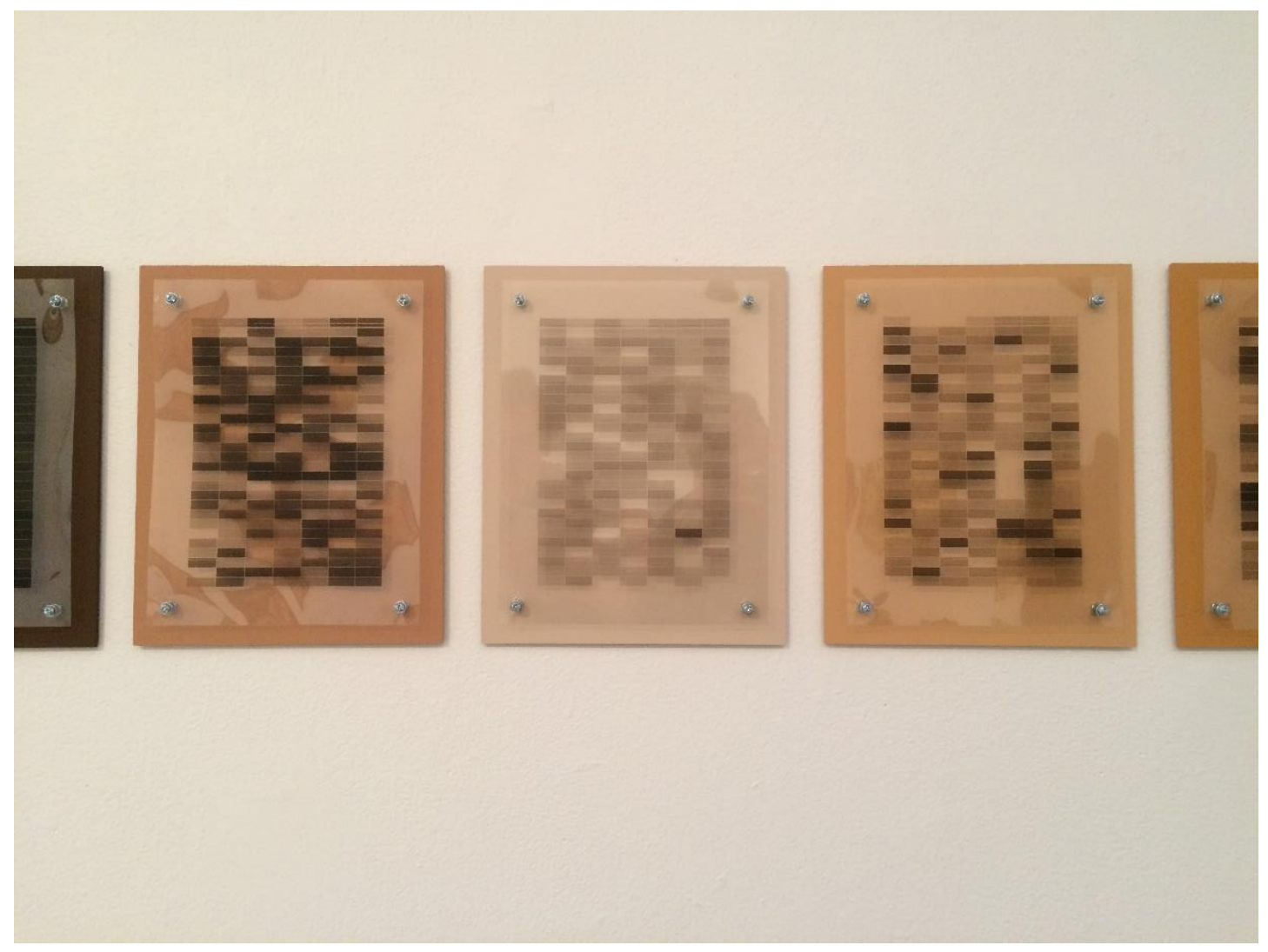

Figure 19. Tessa Lee Martinez, detail of Surface Tension, 2017, masonite, transparencies, paint, and mixed media.

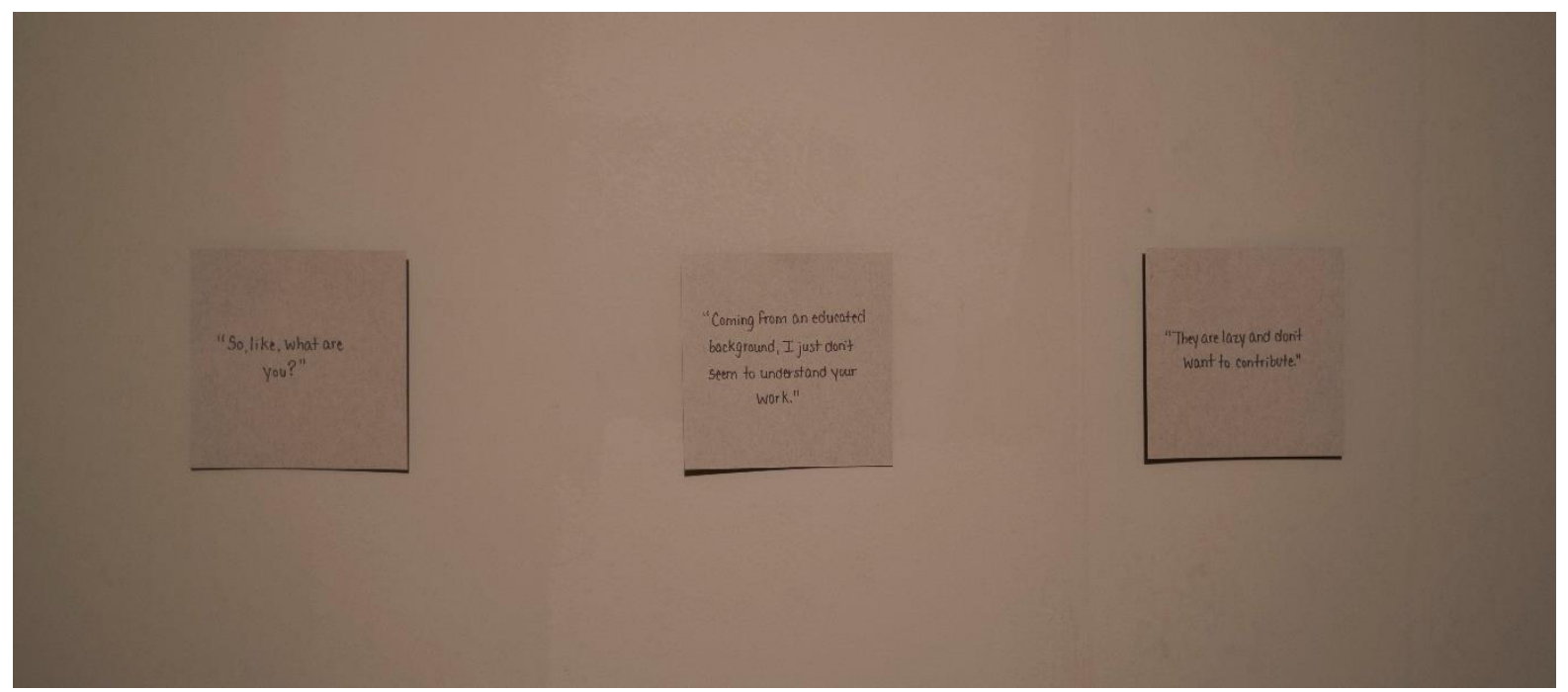

Figure 20. Tessa Lee Martinez, detail of Nada Que Ver, 2018, wood, masonite, joint compound, barbed wire, concrete, paint, paper, sharpie pen. 


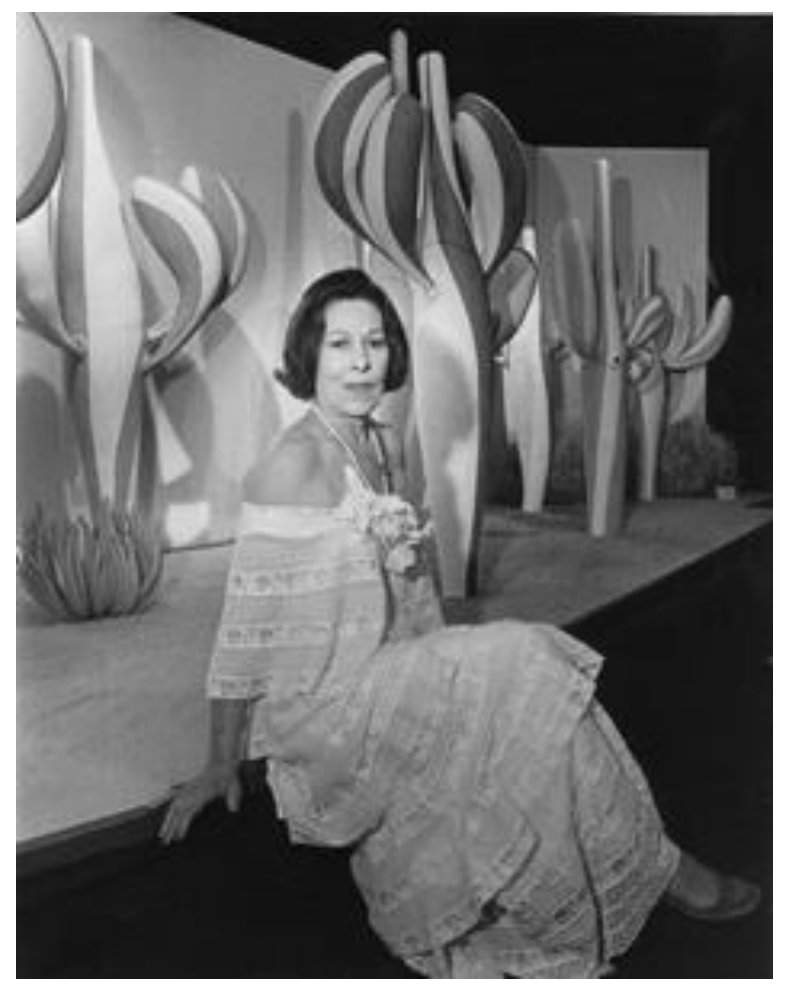

Figure 21. Helen Richter Watson and next to her artwork, n.d. Reproduced from http://www.tamiu.edu/watsongallery/images/HELENR.WATSONBW_full.jpg (accessed April 3, 2018).

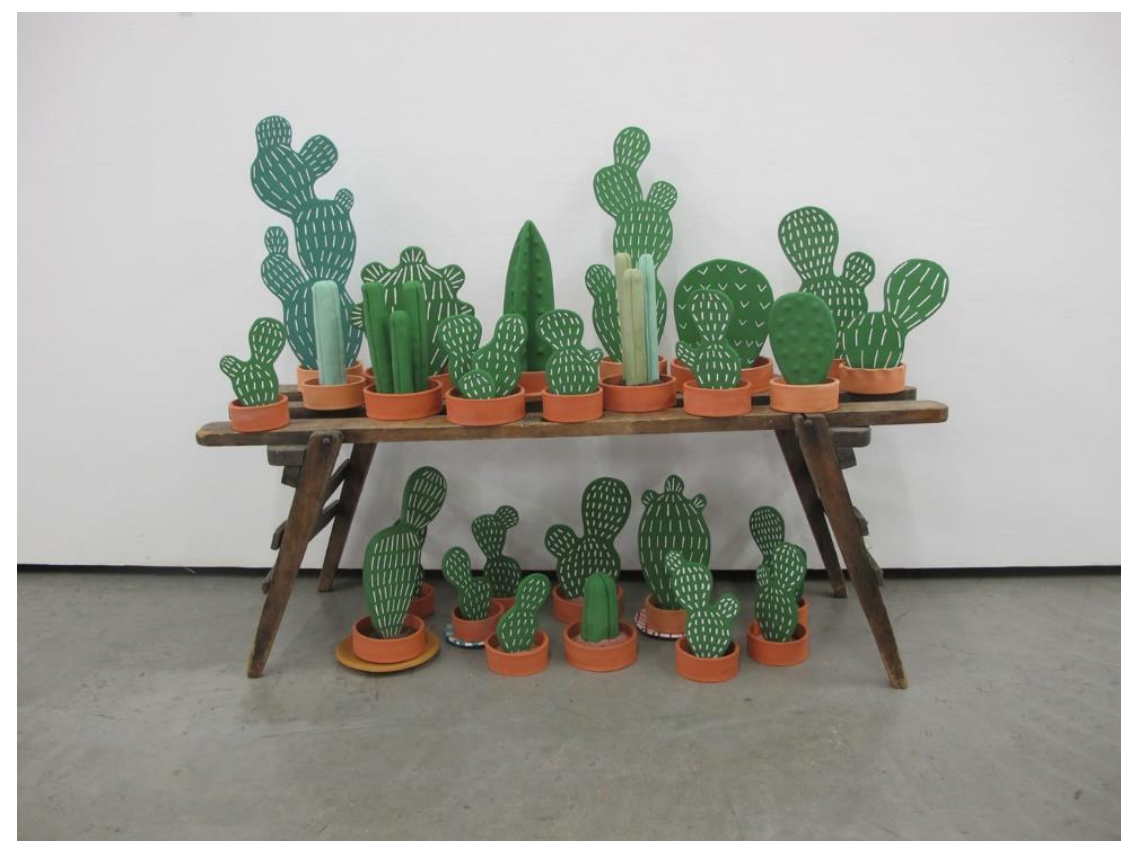

Figure 22. Christina Erives, Sin Titulo, 2016, earthenware, $3.5 \mathrm{ft}$ x $4.5 \mathrm{ft}$ x $2 \mathrm{ft}$. Reproduced from http://www.eriveschristina.com/sin-titulo-1/ (accessed April 1, 2018). 


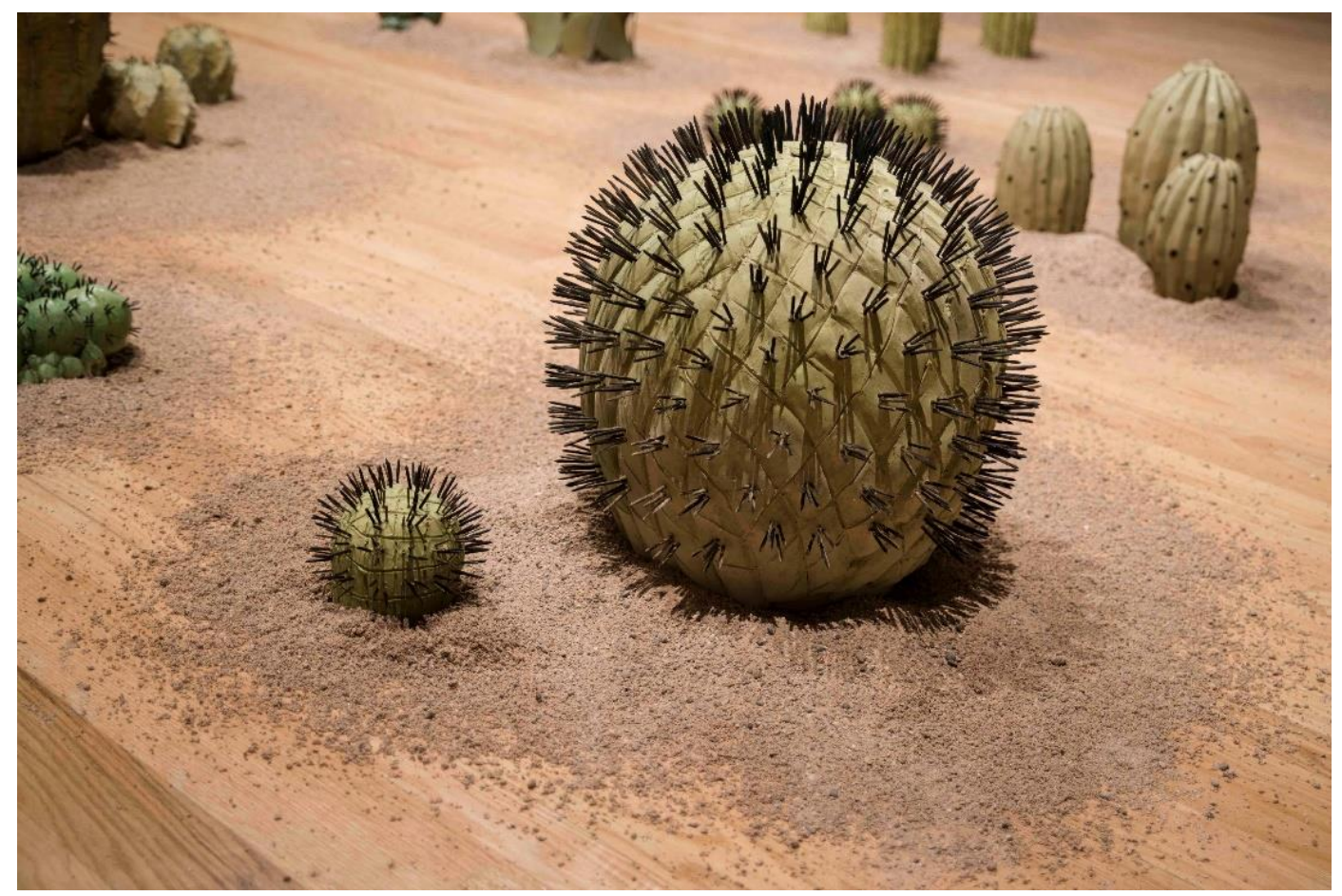

Figure 23. Tessa Lee Martinez, ¡Aguas!, 2018, ceramics and mixed media.

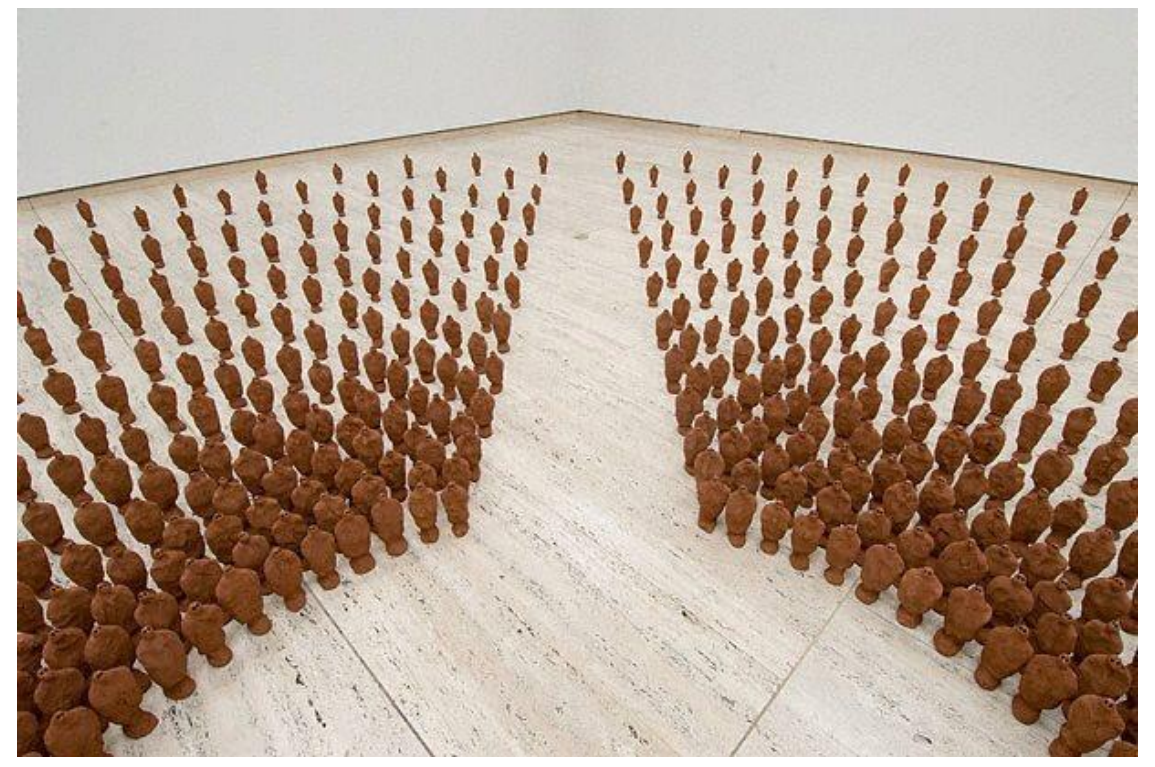

Figure 24. Antony Gormley, Field Project, 1989, terra cotta variable dimensions. Reproduced from https://www.artgallery.nsw.gov.au/collection/works/314.1993/ (accessed March 29, 2018) 


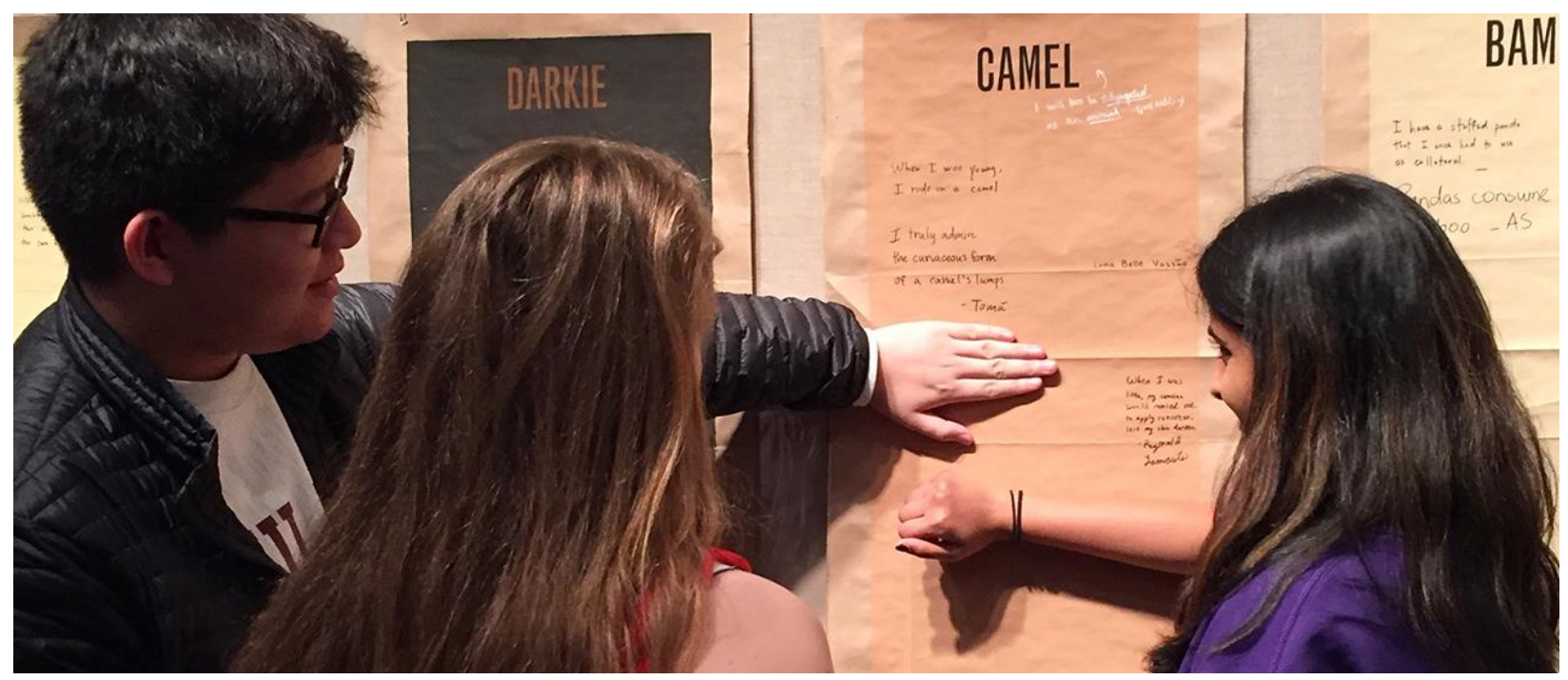

Figure 25. Ila Sahai Prouty, Paper Bag Test, 2016, screen printed paper bags, 40"x variable width. Reproduced from http://ilasahaiprouty.net/ (accessed March 29, 2018).

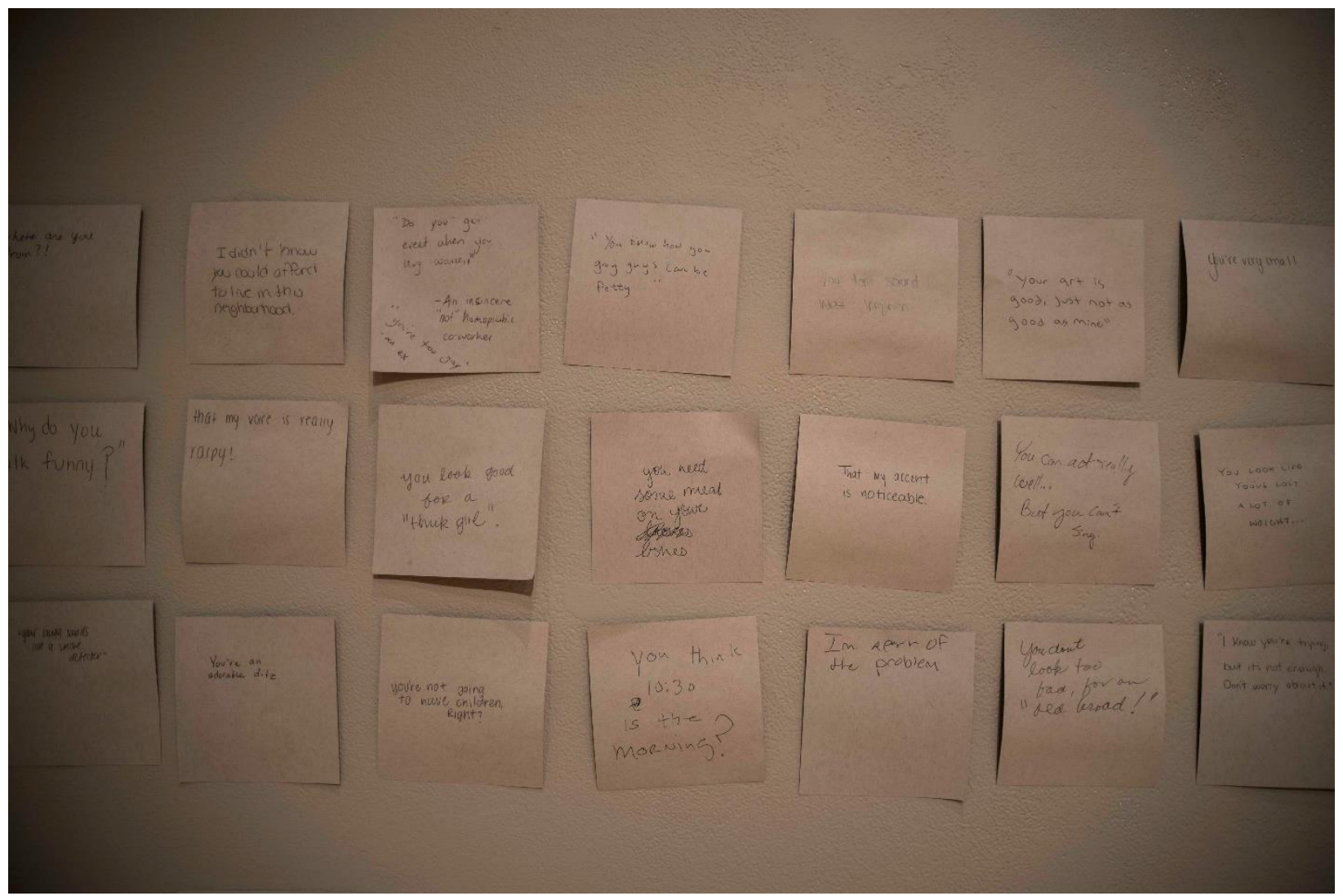

Figure 26. Tessa Lee Martinez, detail of audience responses of Nada Que Ver, 2018, paint, paper, pen. 


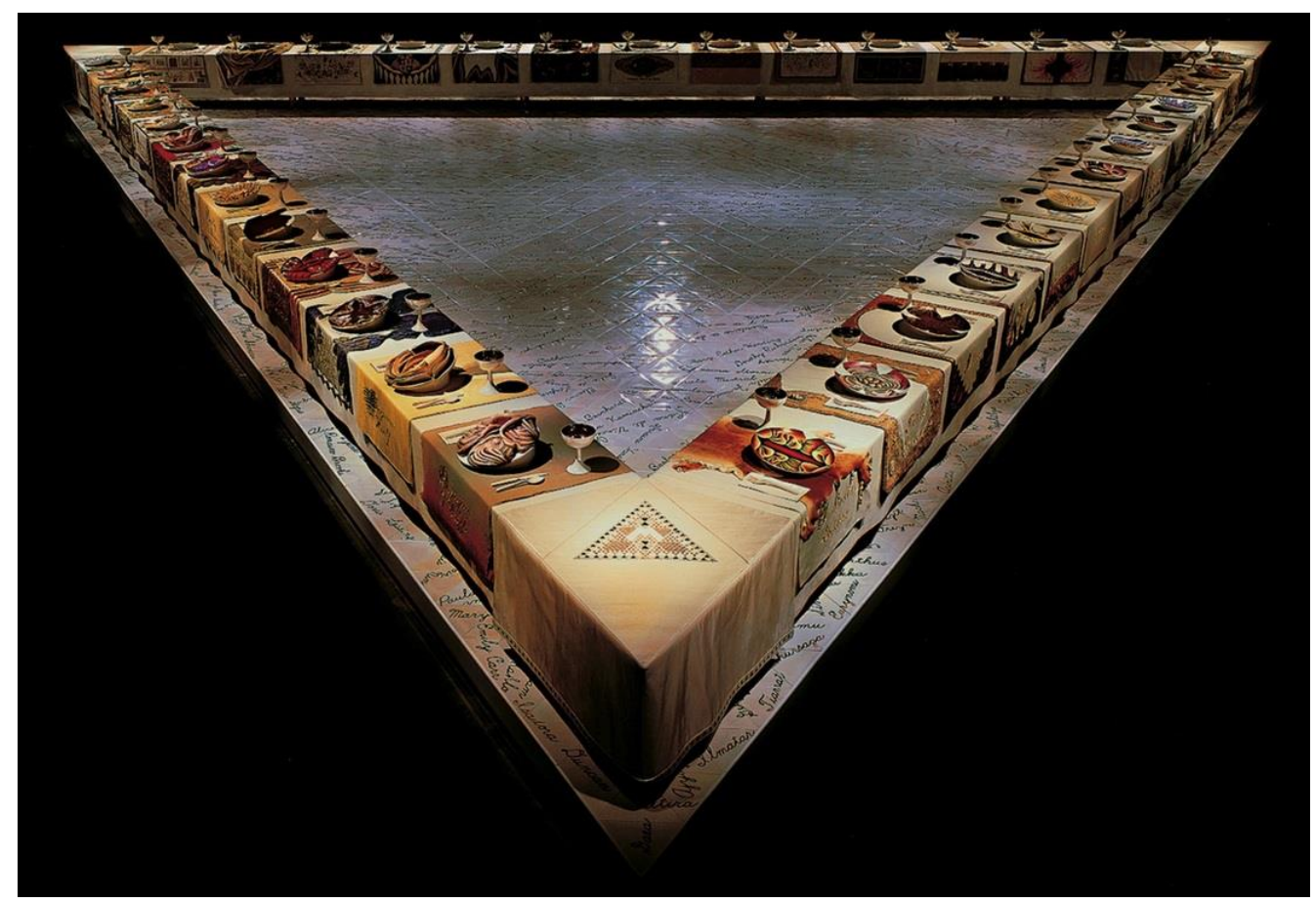

Figure 27. Judy Chicago, The Dinner Party, 1974-1979, ceramic, porcelain, textile, each side 48ft long. Reproduced from https://curiator.com/art/judy-chicago/the-dinner-party (accessed March 8, 2018)

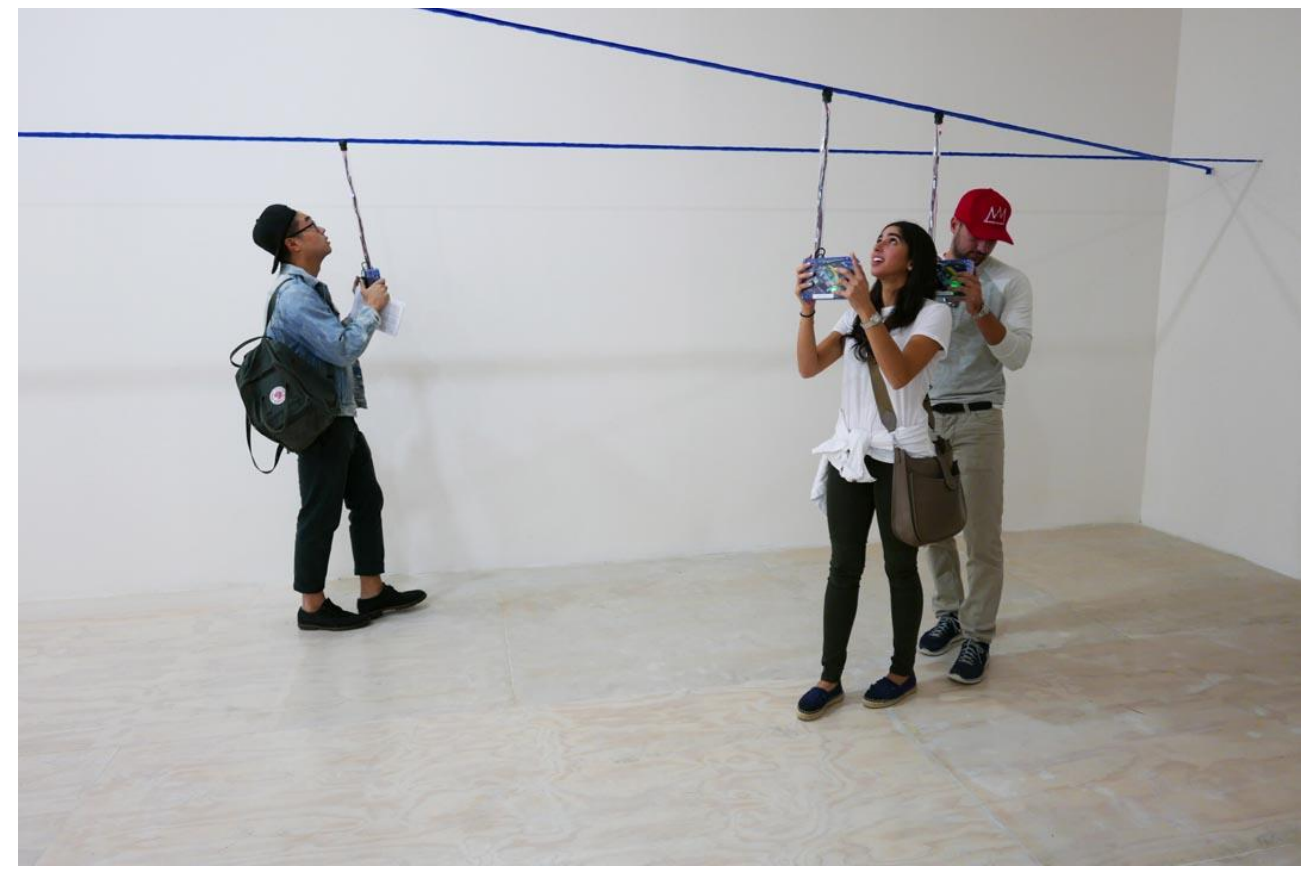

Figure 28. Christine Sun Kim, Game of Skill 2.0, 2015, Velcro, magnets, custom electronics, intern's voice. Reproduced from http://christinesunkim.com/work/game-of-skill-2-0/ (accessed April 2, 2018). 
Dear Friend,

I am black.

I am sure you did not realize this when you made/laughed at/agreed with that racist remark. In the past, I have attempted to alert white people to my racial identity in advance. Unfortunately, this invariably causes them to react to me as pushy, manipulative, or socially inappropriate. Therefore, my policy is to assume that white people do not make these remarks, even when they believe there are no black people present, and to distribute this card when they do.

I regret any discomfort my presence is causing you, just as I am sure you regret the discomfort your racism is causing me.

Figure 29. Adrian Piper, Calling (Card) \#1, 1986, offset lithograph 2in x 31/2in. Reproduced from https://artgallery.yale.edu/collections/objects/218575 (accessed March 5, 2018)

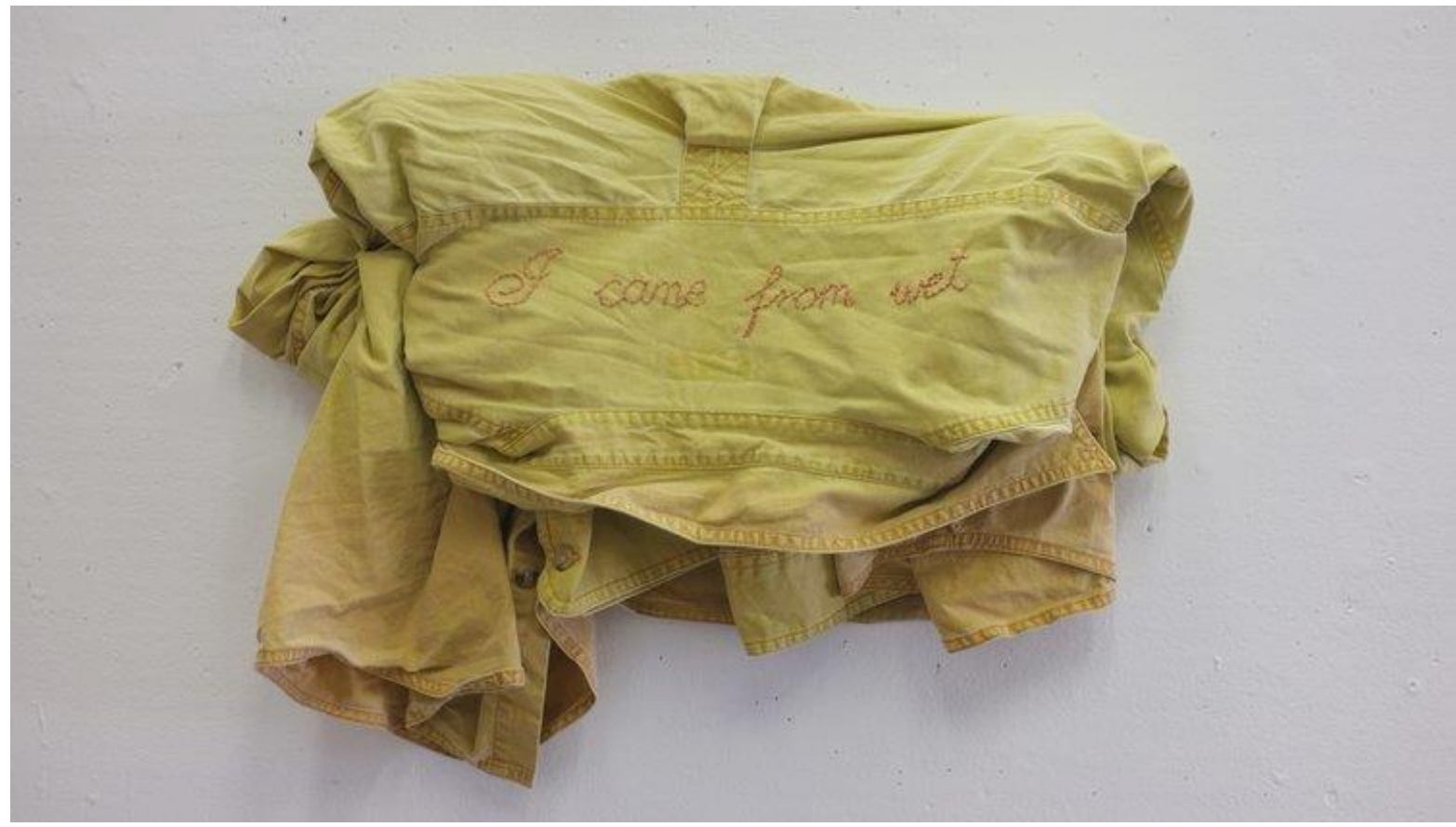

Figure 30. Daniela Cavazos Madrigal, 2017, American Dream, textile. Reproduced from http://danielacavazosmadrigal.com/wear/2ian5dnh4xswnmm49efc9pbqw3ncig (accessed March $5,2018)$. 


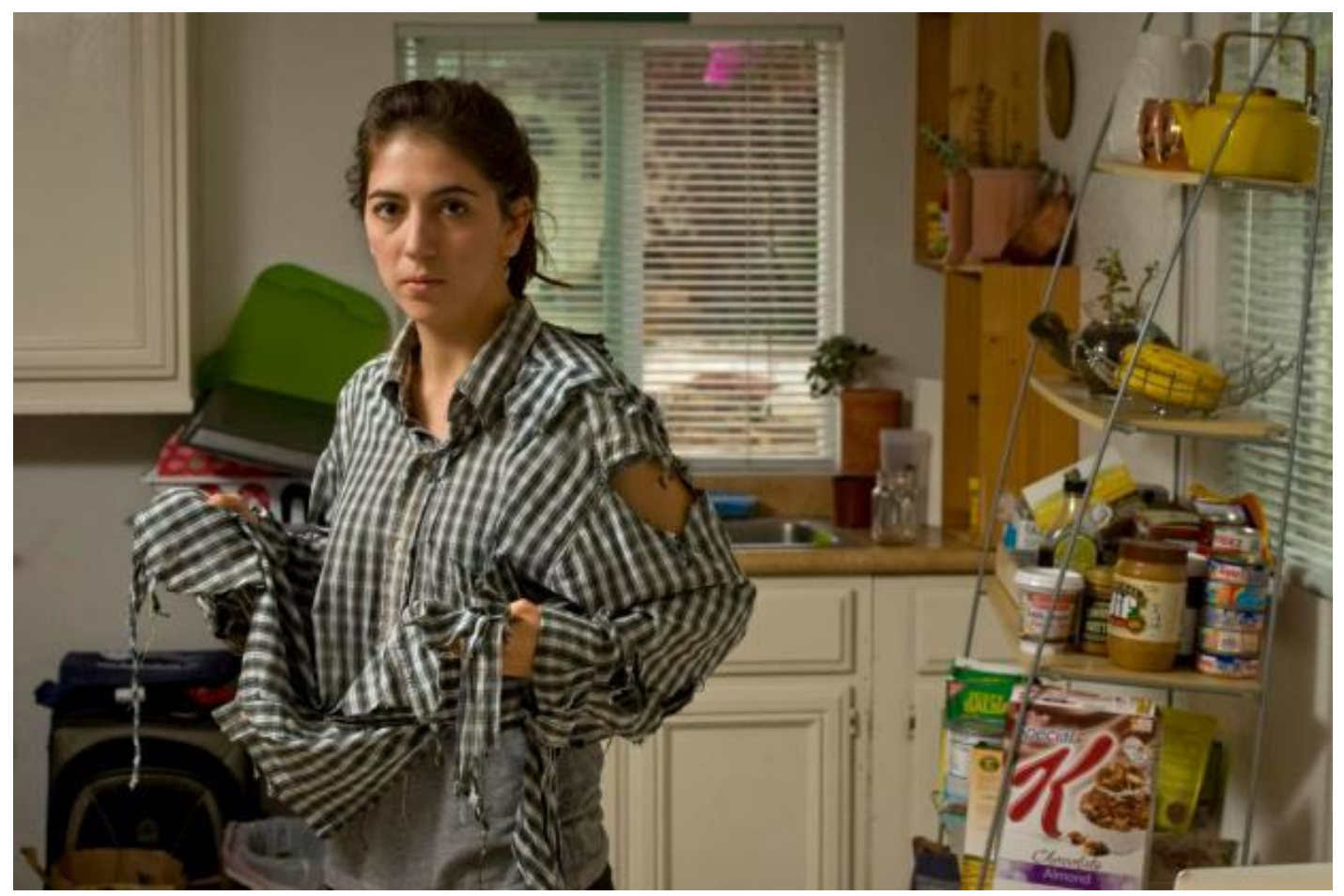

Figure 31. Teresita de la Torre, Todos los Dias, 2015, found shirt. Reproduced from https://www.ocregister.com/2015/05/04/tustin-woman-finds-shirt-along-the-border-wears-it-asperformance-art-to-shed-light-on-immigration/ (accessed April 12, 2018)

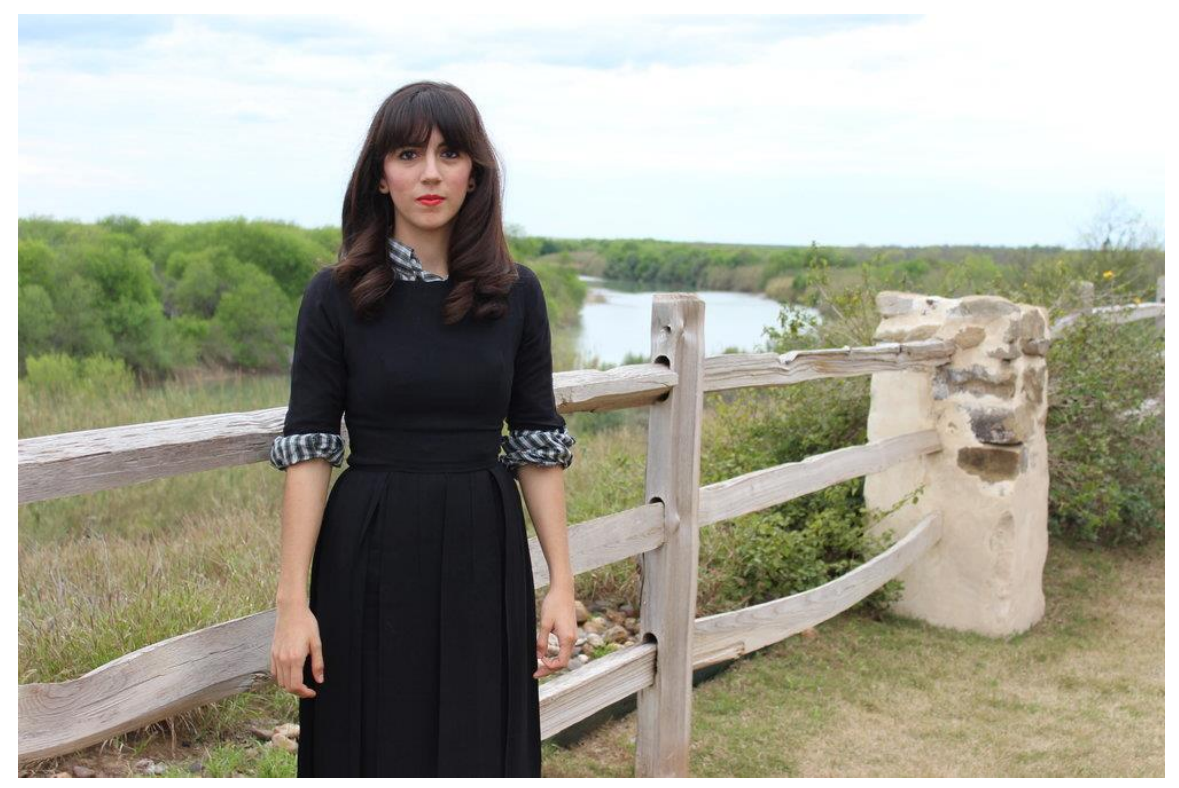

Figure 32. Teresita de la Torre, Todos los Dias, 2015, found shirt, Reproduced from http://todoslosdias-365.com/photographs/6wqlzo1x2u3u2u4vzk3vzwabbzjrll (accessed April 11, 2018) 


\section{BIBLIOGRAPHY}

Archer, Michael, Guy Brett, M. Catherine De Zegher, and Mona Hatoum. Mona Hatoum. [contemporary Artists]. London: Phaidon Press, 1997.

Chicago, Judy. The Dinner Party. New York, N.Y., U.S.A.: Penguin, 1996.

Cisneros, Sandra. The House on Mango Street. First Vintage Contemporaries Edition. ed. Vintage Contemporaries. New York: Vintage Books, a Division of Random House, 1991.

Corby, Vanessa, and Eva Hesse. Eva Hesse : Longing, Belonging and Displacement. New Encounters : Arts, Cultures, Concepts. London: I.B. Tauris, 2010.

Correll, Donovan Stewart, and Marshall Conring Johnston. Manual of the Vascular Plants of Texas. Texas Research Foundation. Contributions, V. 6. Renner, Tex.: Texas Research Foundation, 1970.

Eichstaedt, Peter H. The Dangerous Divide : Peril and Promise on the Us-Mexico Border. Chicago, Illinois: Lawrence Hill Books, 2014.

Fernández, Roberta, and Jean Franco. In Other Words : Literature by Latinas of the United States. Houston, Tex.: Arte Público Press, 1994.

Herring, Cedric, Verna Keith, and Hayward Derrick Horton. Skin Deep : How Race and Complexion Matter in the "color-Blind" Era. Urbana: University of Illinois Press, 2004.

Hesse, Eva, Elisabeth Sussman, San Francisco Museum of Modern Art, and Museum Wiesbaden. Eva Hesse. San Francisco: San Francisco Museum of Modern Art, 2002

Hunter, Margaret L. Race, Gender, and the Politics of Skin Tone. New York: Routledge, 2005.

Mora, Pat. Nepantla : Essays from the Land in the Middle. 1st Ed. ed. Albuquerque: University of New Mexico Press, 1993.

Rebolledo, Tey Diana, and Eliana S Rivero. Infinite Divisions : An Anthology of Chicana Literature. Tucson: University of Arizona Press, 1993.

Sue, Derald Wing. "Microaggressions: More than Just Race." Psychology Today. November 17, 2010. Accessed March 2, 2018.

Trump, Donald John. Speech, Donald Trump's Presidential Announcement Speech, Trump Tower, New York City. June 16, 2015. Accessed March 6, 2018. http://time.com/3923128/donald-trump-announcement-speech/. 


\section{APPENDIX A}

I would like to take this moment to thank Standard Ceramic Supply Company and Lowe's for having the resources that I needed in order to create my work. I am also very appreciative of Wendy's and Dunkin' Donuts for making my late nights in the studio that much easier.

The following people were essential to the success of my work. Without them, I would not have been able to create and install Con el Nopal en la Frente. Manual labor, small repetitive tasks, and words of encouragement really went a long way and I am eternally grateful.

1. Cristina Navarro

2. Clarissa Inocecio

3. Sandy Guajardo

4. Jose "Joe" Flores

5. Gilberto "Gil" Martinez Jr.

6. the Lopez Family

7. Sandra Leal

8. Brigida Sanchez

9. Joshua Singleton

10. Michaela Swiger

11. Anna Jo Nardo

12. Erin Zirkle

13. Andrea Hubbard

14. Hunter McCormick

15. Angela Hewett

16. Max Finniss

17. Shalya Marsh

18. Jeffrey Moser

19. Rhonda Reymond

20. Patsy Weaver

21. Katherine Graham

22. Kristina Olson

23. Janet Snyder

24. Bernie Schultz

25. Amy Schissel

26. Michael Sherwin

27. Dylan Collins

28. Dana Humberson

29. Ken Lu

30. Stephanie Alaniz

31. Xsenia Leshchenko

32. Michael "Ollie" Oliver

33. Feliks Pyron

34. Tiera Tanner

35. Allison Blair

36. Christina Kang

37. Olivia Richardson

38. Kyle Irvin

39. Sarah Mullins

40. Michelle Fegely

41. Jackie Circkirillo
42. Margaret McGaughey

43. Dallas Hartman

44. Ryan Moore

45. Gabrielle Flanary

46. Elisabeth Gray

47. Caitlyn Hall

48. Anna Park

49. Savannah Runner

50. Ryleigh Tennant

51. Madison Witmer

52. Madison Matlick

53. Katelyn Stuckey

54. John "Jay" Jacob Hall

55. Khalil "KJ" Burton

56. Olivia Bostros

57. Kiara Cline

58. Mia James

59. Ian Thomas

60. Heather Rios

61. Nate Ditzler

62. Priscilla Perez

63. Ilian Hernandez Casillas

64. Alec James Martinez

65. San Juanita Perez

66. Elizabeth Rueweler

67. Veronica Gonzalez

68. Monica Martinez

69. Benito Rangel

70. Dee Dee Garcia

71. Ozzi Morzaldi

72. Yvonne Rosas

73. Gabriela Landa

74. Samantha Rodriguez

75. Krystal Jean Newsome

76. Chris Moncivais

77. Jesus Mireles

78. Doris Villarreal

79. Rene Gutierrez

80. Becky Gutierrez

81. Bernardo Diaz

82. Jared Tristan 


\section{APPENDIX B}

The following is a list of the collected responses from the audience on Thursday March 8, 2018, the closing reception of Con el Nopal en la Frente.

1. Do you take anything serious?

2. "you should get a haircut"

3. "I'm not saying that your art is bad, I'm just the style of art is bad"

4. Where are you from?!

5. "Why do you talk funny?"

6. "your laugh sounds like a smoke detector"

7. I didn't know you could afford to live in this neighborhood.

8. that my voice is really raspy!

9. You're an adorable ditz.

10. "Do you get erect when you hug women" -An insecure "not" homophobic co-worker // "You're too gay" -an ex

11. you look good for a "thick girl".

12. you're not going to have children, right?

13. "You know how you gay guys can be petty..."

14. you need some meat on your bones

15. You think 10:30 is the morning?

16. You don't sound West Virginian.

17. That my accent is noticeable.

18. Im a part of the problem

19. "your art is good, just not as good as mine"

20. You can act really well... But you can't sing.

21. You don't look bad, for an "old broad!"

22. you're very small

23. You look like you've lost a lot of weight...

24. "I know you're trying, but it's not enough. Don't worry about it."

25. Did you take your medicine today?

26. Just EAT something!

27. "I don't see your current relationship lasting very long."

28. Are you fatter than you were two years ago? // About Study Art: But you don't have real tests / Its like a hobby, you don't have to work hard

29. "...you only got it because your BLACK"

30. Are you a former marine

31. "Art is easy" //'You are the biggest freak/weirdo I've ever met"

32. You don't look thirty at all.

33. You look like a hipster

34. You look so much nicer with makeup

35. Does your girlfriend speak American good? 
36. Honey Sweetie You don't look that old

37. 'Where are you from?' / (me) Black girl says, "Michigan." / 'Where did your family come from?' / (me) Black girl says, "The African Diaspora." / "You are Lost" / He told me this. I AM NOT LOST.

38. Wow, you're really short!

39. Do you have a different personality?

40. You are much nicer than you look.

41. "youre kind of a princess." // "you have your head in the clouds"

42. "I heard Japanese clits hang lower than Americans' ... is that true?" -A man, when I was in highschool // "But you don't look Asian??" -many people // "You're Asian, that's why you're good at math"

43. I hate you! I love you! Which one is it? It's confusing.

44. "Well yeah, but you're a Christian"

45. "you look emo with that nose ring"

46. Your English is really good! / I answer: Yours is really good too! Are you Dutch?

47. You have a very nice show

48. Go catch me a salmon or something

49. you just don't understand - do you?

50. "I don't know if you READ, BUT..."

51. I love where contacts you look so pretty!

52. What is that?

53. "Wow, was that dance supposed to be full out?"

54 . Why don't you paint landscapes - something people can enjoy?

55. "You'll do fine in college as long as you choose a real major." said to a future artist

56. "You want to be white so bad."

57. "You look like you gained weight... but that's a good thing you looked unhealthy before."

58. "Is your dress on backwards"

59. "Your acne would go away if you just washed your face."

60. "I thought you were going to be a pothead and a cutter but you proved me wrong" - Mrs. Helmstetter

61. Try hard

62. "You're too quiet."

63. "You really get around huh?"

64. You're not like other girls, I mean I think of you as one of the guys

65. "Good like with that" // "Art is Easy" // "You look like you've lost weight"

66. "She makes you look thin"

67. You speak good English.

68. you have really poofy curly hair / must be hard to take care of it

69. you gonna eat all that?

70. So, since you're bi will you leave your boyfriend eventually and get a girlfriend to have biological children? or are you thinking about adoption?

71. Thanks Bud.

72. You're not old you are just like a Grandma! 
73. "you're not that Asian" // "you pass as white" // "I don't see you as not American"

74. Thought you were a bitch before I knew you.

75. Are you okay? You look terrible today

76. I didn't expect you to be smart.

77. Why are you so different?

78. My name is Renatta but in Elementary and Middle School they called me "ratatouille"

79. Being an art major isn't actually hard work right? I mean all you have to do is like... draw stuff.

80. When I am with a man and instead of asking me to help lift things other people will only ask the man. I am strong and my ovaries don't prevent me from lifting...

81. "You need to put on more weight"

82. You've must have gained weight cause you look fat

83. I thought you were conceited before I got to know you.

84. I almost don't hear you accent.

85. Calm down, you're so loud

86. "you need help"

87. When I started out in my broadcast news job a friend who listened said, "If I didn't know it was you, I would have thought it was a professional."

88. You should work harder

89. "You're Asian, but you're white inside"

90. NADA 